THAIS CRISTIANE WAHASUGUI

\title{
ADERÊNCIA, INVASÃO E CITOTOXICIDADE DE Aggregatibacter actinomycetemcomitans ISOLADOS DE PACIENTES PORTADORES DE DOENÇA PERIODONTAL CRÔNICA E AGRESSIVA
}

Tese apresentada ao Programa de PósGraduação em Microbiologia do Instituto de Ciências Biomédicas da Universidade de São Paulo, para obtenção do Título de Doutor em Ciências. 


\section{ADERÊNCIA, INVASÃO E CITOTOXICIDADE DE Aggregatibacter actinomycetemcomitans ISOLADOS DE PACIENTES PORTADORES DE DOENÇA PERIODONTAL CRÔNICA E AGRESSIVA}

Tese apresentada ao Programa de PósGraduação em Microbiologia do Instituto de Ciências Biomédicas da Universidade de São Paulo, para obtenção do Título de Doutor em Ciências.

Área de concentração: Microbiologia

Orientador: Prof. Dr. Mario Julio Avila-Campos

Versão original 


\section{DADOS DE CATALOGAÇÃO NA PUBLICAÇÃO (CIP)}

Serviço de Biblioteca e Informação Biomédica do

Instituto de Ciências Biomédicas da Universidade de São Paulo

(c) reprodução total

Wahasugui, Thais Cristiane.

Aderência, invasão e citotoxicidade de Aggregatibacter

actinomycetemcomitans isolados de pacientes portadores de doença periodontal crônica e agressiva / Thais Cristiane Wahasugui. -- São Paulo, 2013.

Orientador: Prof. Dr. Mario Júlio Ávila-Campos.

Tese (Doutorado) - Universidade de São Paulo. Instituto de Ciências Biomédicas. Departamento de Microbiologia. Área de concentração: Microbiologia. Linha de pesquisa: Bacteriologia de anaeróbios.

Versão do título para o inglês: Adhesion, invasion and cytotoxicity of Aggregatibacter actinomycetemcomitans isolated from patients with chronic and aggressive periodontal disease.

1. Aggregatibacter actinomycetemcomitans 2. Periodontite crônica e agressiva 3. Virulência bacteriana 4. Citotoxinas 5. Biofilmes orais I. Avila-Campos, Prof. Dr. Mario Julio II. Universidade de São Paulo. Instituto de Ciências Biomédicas. Programa de Pós-Graduação em Microbiologia III. Título. 
Candidato(a): $\quad$ Thais Cristiane Wahasugui.

Título da Tese: $\quad$ Aderência, invasão e citotoxicidade de Aggregatibacter actinomycetemcomitans isolados de pacientes portadores de doença periodontal crônica e agressiva.

Orientador(a):

Prof. Dr. Mario Júlio Ávila Campos.

A Comissão Julgadora dos trabalhos de Defesa da Tese de Doutorado, em sessão pública realizada a $. .1 .$. considerou
( ) Aprovado(a)
( ) Reprovado(a)

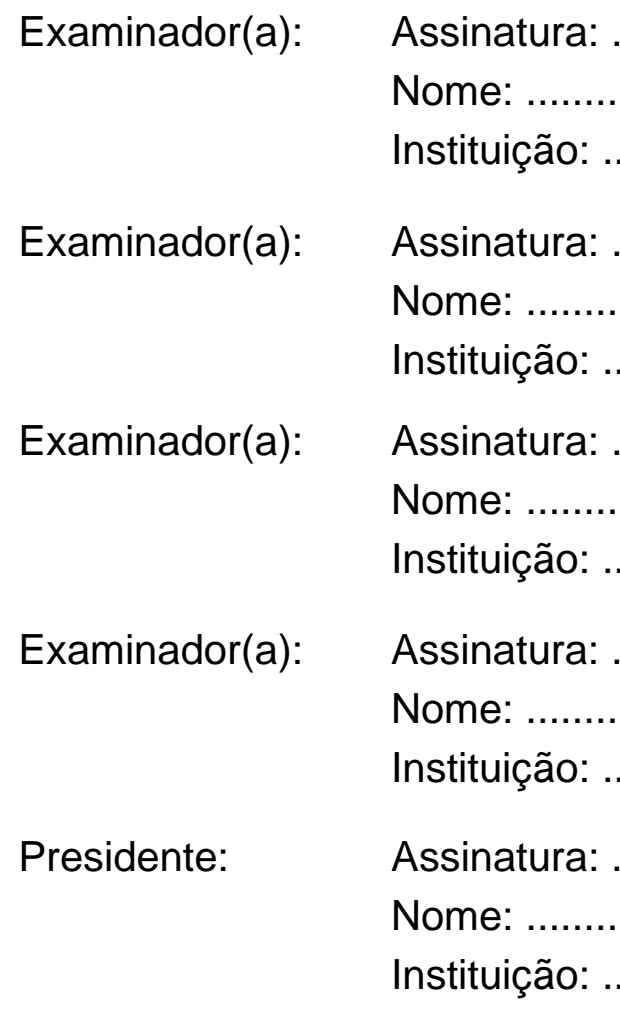




\section{PARECER $662 / \mathrm{CEP}$}

São Paulo, 11 de agosto de 2005.

Prezada Senhora,

Atendendo sua solicitação, a Comissão de Ética em Pesquisas com Seres Humanos do ICB, em sua qüinquagésima sêtima reunião, analisou o projeto de sua responsabilidade intitulado: "Ocorrência dos genes calt E ltx Actinobacillus actinomycetemcomitans isolados de pacientes portadores e não portadores de doença periodontal".

Informo a V.Sa. que, após anâlise e discussão, o referido projeto foi aprovado por esta Comissão.

Esclareço a V.Sa. que dentro de 12 meses, relatório do referido projeto deverá ser encaminhado à Secretaria deste CEP.

Atenciosamente,

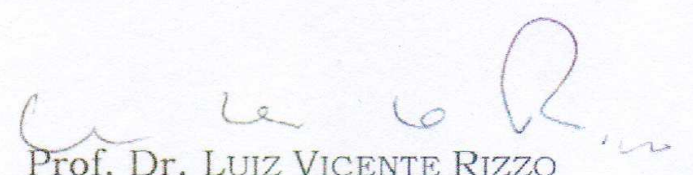

Prof. Dr. Luiz Vicente Rizzo

Coordenador da Comissão de Ética em Pesquisas com Seres Humanos - ICB/USP

Ilma. Sra.

THAIS CRISTIANE WAHASUGUI

Departamento de Microbiologia

Instituto de Ciências Biomédicas -USP 
À minha querida avó, Mitsuko Abe, por todo amor, cuidado, compreensão e proteção dedicados à mim. Por ter me incentivado a estudar por toda a vida, pelo bem das pessoas.

Aos meus queridos pais, Rosa e Tadashi, por todos os esforços empreendidos em meu crescimento como pessoa e como profissional. Por terem me ensinado os valores do respeito e da gratidão.

À minha querida irmã, Kelly, por ser amiga, conselheira, mãe, por me ouvir e me guiar com sabedoria nos momentos mais difíceis. Pelo apoio imprescindível, para o início e término desse trabalho. Ao meu querido cunhado Renato, por sua generosidade, apoio e carinho.

Ao meu querido marido, Tiago, que se esforça diariamente em prol do meu bem-estar, meu grande companheiro de vida. Que sempre está ao meu lado nos momentos em que mais preciso, me oferecendo carinho e proteção.

Aos meus queridos sogros, Creuza e Luis; cunhados, Juliana e Fernando e aos familiares de meu marido, por todo o apoio e carinho.

Aos meus queridos tios, tias e primos, pelos cuidados, carinho e incentivos dedicados à mim.

$\mathcal{A}$ todos os meus familiares e amigos, que sempre me acompanharam e torceram por cada uma de minhas conquistas.

Ao meu querido mestre de vida, Dr. Daisaßu I Keda, que através de seus sinceros incentivos, me encoraja para que eu jamais desista dos meus sonhos. 


\section{AGRADECIMENTOS}

Ao meu orientador, Prof. Dr. Mario Julio Avila-Campos, por ter me dado a oportunidade de realizar esse trabalho, por sua dedicação, paciência, incentivos, ensinamentos e carinho.

À amiga Viviane Nakano Katz, pela amizade, carinho, auxílio, ensinamentos e significativa colaboração na parte experimental desse estudo.

Aos amigos do Laboratório de Anaeróbios, Amanda N. Silva, Alessandra M. Oliveira, Elessandra M. Silvestro, Luiz F. Tomazinho, Fernanda Almeida, Gerusa N. A. Senhorinho, Amélio Taveira, Elerson G. J. Júnior, Antonio S. Fabris, Victor R. C. Merino, Viviane A. Arenas Rodrigues, Luiz A. L. Albornoz, Alfredo C. R. Feitosa, Sheila A. B. Nishiyama, Aline I. S. Silva, Mirian R. Fernandes por tudo o que me ensinaram durante esses anos de convivência e amizade, pelo carinho e auxílio.

À Zulmira Alves, por realizar o apoio técnico com toda atenção, para que pudesse desenvolver da melhor forma minha pesquisa, por seu carinho, amizade, incentivo e alegria. Também, à Marcia H. Fukugaiti, pelo apoio técnico e amizade.

À Profa. Dra. Silvana Cai do Laboratório de Microbiologia Oral, do Departamento de Microbiologia - Instituto de Ciências Biomédicas (ICB) - USP, por ter me dado a oportunidade de encontrar meu caminho na Pós-Graduação.

A todos os professores do curso de Pós-Graduação do Departamento de Microbiologia - ICB - USP, pela transmissão de conhecimento, convivência e amizade.

Aos secretários do Departamento de Microbiologia, Alice Shimabuku, Anamaria Amaral, Naide Farripas, Gisele G. Santana e da Pós-Graduação do ICB, Celso Pereira e Luciana da Silva pelo atendimento cordial. 
Aos funcionários da Biblioteca do ICB, pela gentileza nos atendimentos prestados.

Aos funcionários do Setor de Apoio Técnico do Departamento de Microbiologia do ICB, pelo apoio, auxílio e amizade.

Aos Profs. Drs. Giorgio de Micheli, Giuseppe A. Romito e Francisco E. Pustiglioni do Departamento de Estomatologia, da Faculdade de Odontologia (FO) - USP, pela autorização para realizar as coletas de amostras dos pacientes nas Clínicas de Periodontia.Também, à amiga Silvia L. Marcelino, pela colaboração, amizade e carinho.

À Profa. Dra. Roxane M. F. Piazza do Laboratório de Bacteriologia, do Instituto Butantan, pela importante colaboração, atenção e carinho. Assim como, aos amigos Sarita S. Rossato, Júlia M. Nara, Márcio A. Menezes, Letícia B. Rocha, Keyde C. M. Melo, Hebert F. Culler, pelo apoio, auxilio na realização dos experimentos e amizade.

A todos aqueles que, de alguma maneira, contribuíram para a concretização desse trabalho.

Ao Conselho Nacional de Desenvolvimento Científico e Tecnológico (CNPq) e à Fundação de Amparo à Pesquisa do Estado de São Paulo (FAPESP), pelos auxílios financeiros. 
"Certa vez, havia três pessoas que carregavam tijolos. Um transeunte perguntou a eles: 'O que estão fazendo?' A primeira pessoa respondeu: 'Estou carregando pedras'. A segunda: 'Estou levantando paredes'. E a terceira respondeu orgulhosamente: 'Estou construindo um templo'".

René Dubos

"Uma simples tarefa pode salvar a humanidade, tudo depende do sentimento e do sincero desejo de realizála". 


\section{RESUMO}

WAHASUGUI, T. C. Aderência, invasão e citotoxicidade de Aggregatibacter actinomycetemcomitans isolados de pacientes portadores de doença periodontal crônica e agressiva. 2013. 62 f. Tese (Doutorado em Microbiologia) Instituto de Ciências Biomédicas, Universidade de São Paulo, São Paulo, 2013.

Aggregatibacter actinomycetemcomitans exerce um papel fundamental no desenvolvimento da doença periodontal crônica e agressiva. Produz fatores de virulência que o tornam capaz de colonizar e invadir os tecidos periodontais e de escapar das defesas do hospedeiro. Nesse estudo, foram determinadas as características fenotípicas e genotípicas de $A$. actinomycetemcomitans e a presença dos principais genes responsáveis por sua virulência. Amostras de biofilme subgengival de 65 indivíduos com doença periodontal e de 48 indivíduos sadios foram coletadas, sendo obtidos 73 isolados bacterianos. Testes de biotipagem, adesão, invasão e citotoxicidade às células orais (KB), produção de neuraminidase $e$ biofilme, presença de cápsula e fimbrias foram avaliados, assim como, a presença dos genes flp-1 (relacionado à adesão); apaH (relacionado à invasão); promotor LTX e ItxA (produção de leucotoxina); e $\operatorname{cdt} A, \operatorname{cdt} B, \operatorname{cdt} C, \operatorname{cdt} A B C$ (produção de toxina distensora). $O$ biotipo II foi 0 mais predominante nos isolados de $A$. actinomycetemcomitans. Sessenta e seis isolados foram capazes de aderir às células KB e dentre eles, 33 foram capazes de invadir as mesmas. Quarenta e seis isolados de $A$. actinomycetemcomitans foram citotóxicos às células $\mathrm{KB}$, produzindo alterações na morfologia celular. Neuraminidase foi produzida por 60 dos isolados analisados, com títulos de aglutinação de 2 a 8 . Cinquenta e quatro isolados foram capazes de formar grande quantidade de biofilme. Todos os isolados apresentaram cápsula, porém nenhum deles apresentou fímbrias. O gene flp-1 foi detectado em 40 isolados e o gene apaH em 52 isolados de $A$. actinomycetemcomitans. $\mathrm{O}$ promotor LTX e o gene ItXA foram encontrados em todos os isolados, sendo 64 altamente leucotóxicos e 9 fracamente leucotóxicos. O gene cdt $A$ foi observado em 50 isolados testados; o gene $c d t B$, em 48 isolados; o gene $c d t C$, em 61 isolados e o gene $c d t A B C$, em 40 isolados. Esses resultados sugerem que a maioria dos isolados clínicos de $A$. actinomycetemcomitans, provenientes de pacientes com periodontite, abrigam os principais genes responsáveis pela virulência, principalmente os relacionados à produção de toxinas. Possivelmente, a maioria dos isolados foram capazes de aderir às células orais e formar biofilmes em superfícies sólidas pelo envolvimento de outros tipos de adesinas, além das fímbrias. Além disso, dois dos três isolados de indivíduo sadio também apresentaram fatores de virulência que poderiam causar periodontite.

Palavras-chave: Aggregatibacter actinomycetemcomitans. Periodontite crônica e agressiva. Virulência bacteriana. Citotoxinas. Biofilmes orais. 


\begin{abstract}
WAHASUGUI, T. C. Adhesion, invasion and cytotoxicity of Aggregatibacter actinomycetemcomitans isolated from patients with chronic and aggressive periodontal disease. 2013. 62 p. Ph. D. thesis (Microbiology) - Instituto de Ciências Biomédicas, Universidade de São Paulo, São Paulo, 2013.

Aggregatibacter actinomycetemcomitans plays a key role in the development of chronic and aggressive periodontitis. This microorganism produces virulence factors which make it able to colonize and invade the periodontal tissues and escape from host defenses. In this study, the phenotypic and genotypic characteristics of $A$. actinomycetemcomitans and the presence of the main genes responsible for virulence were determined. Subgingival biofilm samples from 65 patients with periodontal disease and 48 healthy individuals were collected, and 73 bacterial isolates were obtained. Biotyping, adhesion, invasion and cytotoxicity to oral cells (KB), neuraminidase and biofilm production, presence of capsule and fimbriae were evaluated, as well as the presence of $f / p-1$ (related to adhesion); apaH (related to invasion); LTX promoter and ItxA (leukotoxin production); $c d t A, c d t B, c d t C, c d t A B C$ (cytoletal distending toxin production) genes. Biotype II was the most prevalent in $A$. actinomycetemcomitans. Sixty-six isolates were able to adhere to KB cells and among them 33 were able to invade them. Forty-six A. actinomycetemcomitans isolates were cytotoxic to KB cells, producing changes in cell morphology. Neuraminidase was produced by 60 isolates, with agglutination titles of 2 to 8 . Fiftyfour $A$. actinomycetemcomitans were able to form large amount of biofilm. All isolates showed capsule, but not fimbriae. The flp-1 and apaH genes were detected, respectively, in 40 and 52 isolates. The LTX promoter and ItxA gene were found in all isolates, in 64 were highly leukotoxic and 9 minimally leukotoxic. The cdtA gene was observed in 50; cdtB in 48; cdtC in 61 and cdtABC in 40 A. actinomycetemcomitans. These results suggest that most of $A$. actinomycetemcomitans clinical isolates from periodontal patients, harbor the main genes responsible for virulence, especially those related to toxins production. Possibly, most of the isolates were able to attach to oral cells and form biofilms on solid surfaces, by the involvement of other types of adhesins, besides the fimbriae. Furthermore, two out three isolates from healthy individual also had virulence factors that could cause periodontitis.
\end{abstract}

Keywords: Aggregatibacter actinomycetemcomitans. Chronic and aggressive periodontitis. Bacterial virulence. Cytotoxin. Oral biofilms. 


\section{LISTA DE ILUSTRAÇÕES}

Figura 1 - Padrão de adesão de A. actinomycetemcomitans (a) e E. coli O127:H6 (E2348/69) (enteropatogênica) (b) às células orais KB.

Figura 2 - Detecção de genes apaH (a), flp1 (b), cdtA (c), cdtB (d), cdtC (e), $\operatorname{cdt} A B C(\mathrm{f})$, ItxA $(\mathrm{g})$ e promotor LTX (h) em $A$. actinomycetemcomitans.. .32 


\section{LISTA DE TABELAS}

Tabela 1 - Oligonucleotídeos, temperatura de anelamento e tamanho dos amplicons usados na detecção de genes

Tabela 2 - Características clínicas dos pacientes com doença periodontal e dos pacientes sadios, com amostras positivas para $A$. actinomycetemcomitans

Tabela 3 - Adesão e invasão às células KB de $A$. actinomycetemcomitans isolados de pacientes com periodontite e de indivíduos sadios

Tabela 4 - Presença de genes em $A$. actinomycetemcomitans isolados de pacientes com periodontite e de indivíduos sadios. 
1 INTRODUÇÃO

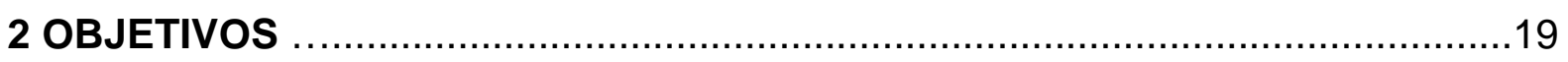

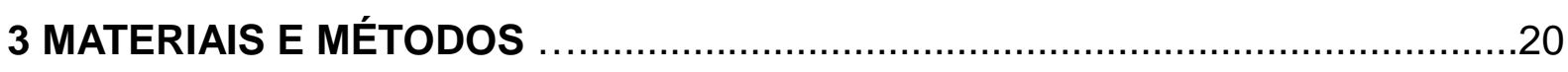

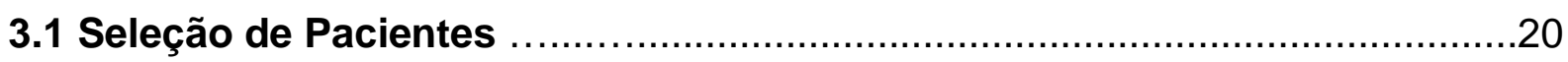

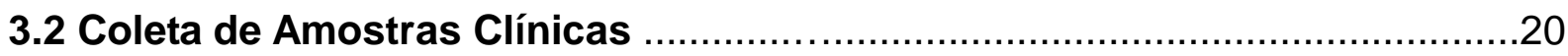

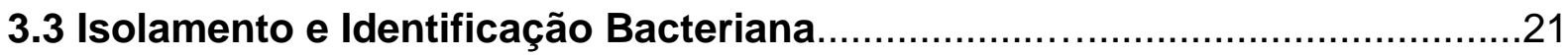

3.4 Biotipagem

3.5 Caracterização Fenotípica de Alguns Fatores de Virulência........................22

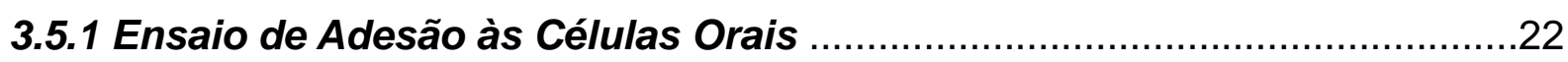

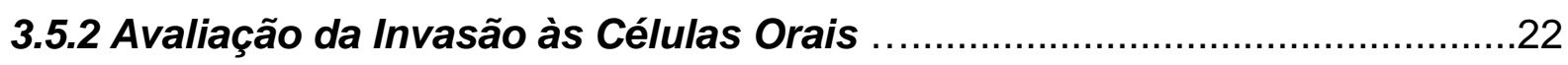

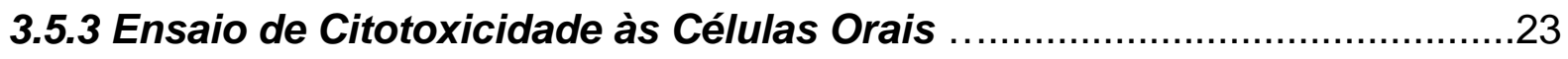

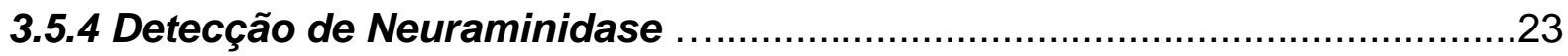

3.5.5 Inibição da Atividade de Neuraminidase …..........................................24

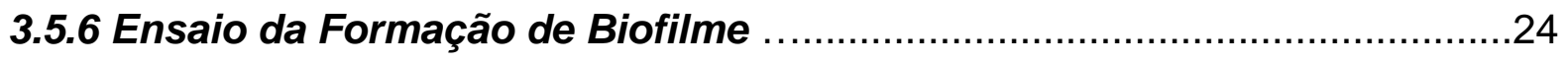

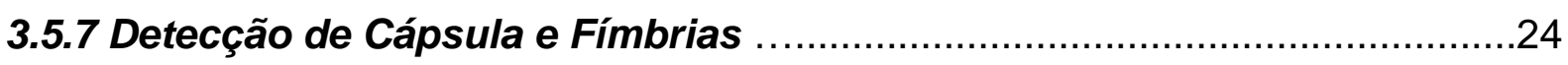

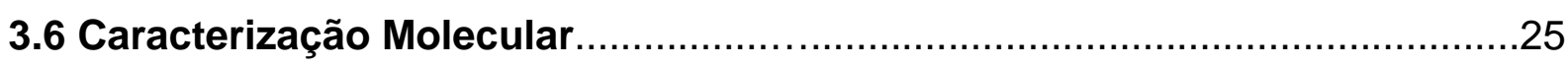

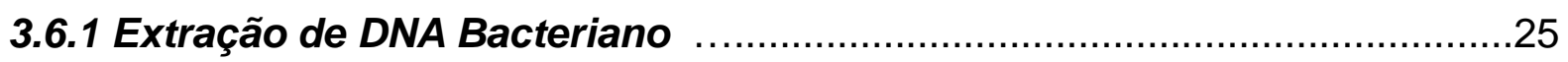

3.6.2 Detecção dos Genes flp-1 (adesão), apaH (invasão), Itx (leucotoxina) e cdt (toxina distensora) por Reação em Cadeia da Polimerase (PCR) ....................25

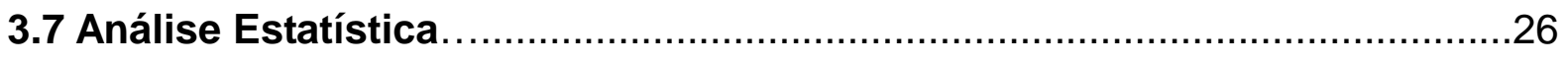

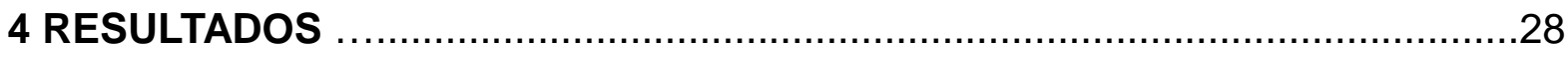

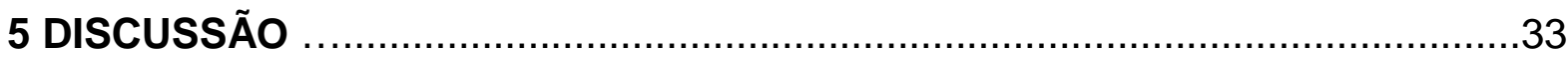

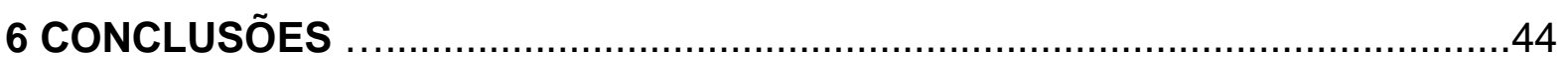

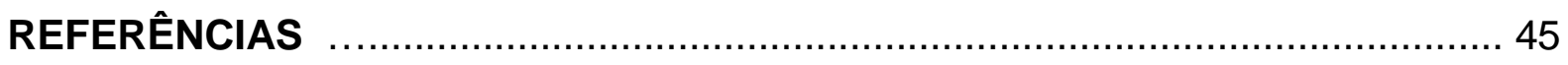

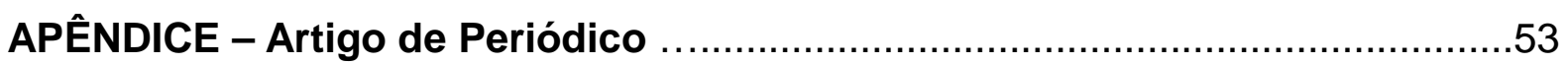




\section{INTRODUÇÃO}

A doença periodontal é um processo complexo, onde ocorre a interação entre o biofilme subgengival e a resposta imunológica do hospedeiro por meio de eventos imuno-inflamatórios que se desenvolvem nos tecidos gengivais e periodontais em resposta aos desafios apresentados por microrganismos (GENCO, 1992). Dentre as patologias periodontais, a periodontite crônica constitui-se a forma mais comumente observada nos pacientes, particularmente na idade adulta, diferentemente da periodontite agressiva que afeta principalmente indivíduos jovens (ASIKAINEN et al., 1997; LINDHE et al., 1999). Em ambos os casos, a formação do biofilme subgengival é um dos fatores essenciais para o estabelecimento, desenvolvimento e progressão da doença periodontal, aliados também aos fatores locais, sistêmicos e ambientais que influenciam diretamente na relação de equilíbrio hospedeiromicrobiota.

No Workshop Internacional para a Classificação das Condições e das Doenças Periodontais, em 1999, os termos "periodontite de início precoce" e "periodontite do adulto" foram substituídos por "periodontite agressiva" e "periodontite crônica", respectivamente. Tais mudanças ocorreram devido à enfase inapropriada na idade do indivíduo e nas taxas de progressão da doença (ARMITAGE, 1999). Atualmente, periodontite agressiva e periodontite crônica são reconhecidas como duas formas distintas de doença periodontal.

A periodontite agressiva é caracterizada principalmente por acometer vários membros de uma mesma família, assim como pela rápida perda de inserção e destruição óssea periodontal em indivíduos sadios (exceto pela presença da periodontite); ocorre geralmente em pacientes com menos de 30 anos de idade, podendo estar presente em adultos com mais de 30 anos. Por outro lado, a periodontite crônica é definida como uma doença infecciosa que leva à perda progressiva, lenta ou moderada, de inserção e osso alveolar, sendo mais prevalente em adultos com mais de 30 anos de idade, embora possa ocorrer em crianças e adolescentes. Ambos podem ser caracterizados pela extensão (formas generalizada ou localizada) e severidade (formas leve, moderada e severa). Elevadas proporções de Aggregatibacter actinomycetemcomitans e em algumas populações, de Porphyromonas gingivalis, foram reconhecidas como uma das características secundárias que estão frequentemente presentes na periodontite agressiva 
(ARMITAGE, 1999).

Aggregatibacter actinomycetemcomitans é um cocobacilo anaeróbio capnofilico, Gram-negativo, imóvel, não formador de esporos e, principalmente, um importante patógeno que vem sendo foco de estudo para muitos pesquisadores (WILSON et al., 1995). Esse microrganismo está associado à várias doenças infecciosas, tais como endocardite, meningite, abscessos, septicemia, e osteomielite (MUHLE et al., 1979; PAGE; KING, 1966). Entretanto, seu principal papel se destaca na etiologia da doença periodontal em suas várias formas, incluindo a periodontite agressiva localizada, periodontite crônica e periodontite refratária (SLOTS et al., 1986; ZAMBON et al., 1996). Estudos também têm mostrado a participação deste microrganismo como microbiota residente da cavidade bucal, em pacientes com evidências clínicas de saúde periodontal (TAN; SONG; ONG, 2002).

Fatores de virulência são atributos de um microrganismo que o capacitam a colonizar um nicho particular em seu hospedeiro, superar seu sistema de defesa, iniciando o processo de doença. Aggregatibacter actinomycetemcomitans possui inúmeros de fatores de virulência que aumentam sua sobrevivência na cavidade oral e o tornam capaz de driblar as estratégias protetoras do hospedeiro. Muitos desses fatores de virulência podem estar envolvidos na patogênese da periodontite (FIVESTAYLOR et al., 1999).

A colonização do sulco gengival e, posteriormente, da bolsa periodontal constitui-se o passo inicial da doença periodontal. A habilidade de bactérias se aderirem às superfícies da cavidade oral é essencial para a colonização existindo, portanto, grande interesse no entendimento dos mecanismos pelos quais $A$. actinomycetemcomitans coloniza as células do hospedeiro (ROSE; MEYER; FIVESTAYLOR, 2003).

O processo de adesão à superfície dos tecidos do hospedeiro é considerado o pré-requisito para a colonização bacteriana. A. actinomycetemcomitans tem a habilidade de se aderir às células epiteliais da mucosa oral e às superfícies dentais, assim como realiza a coagregação com outras bactérias, sendo também capaz de invadir células orais. Esses são considerados os principais passos para a patogênese das doenças periodontais. Estes mecanismos de adesão e invasão de A. actinomycetemcomitans às células epiteliais, certamente envolvem interações específicas e não específicas, com a participação de outros reguladores deste processo, os quais ainda não estão totalmente elucidados (MEYER; FIVES- 
TAYLOR, 1994).

Estudos indicam que a capacidade de aderência de $A$. actinomycetemcomitans às células epiteliais bucais ou à hidroxiapatita estaria associada às fímbrias, vesículas extra-celulares e material amorfo extracelular observados em nível ultraestrutural (MEYER; FIVES-TAYLOR, 1994).

As fímbrias são estruturas importantes para a adesão e para formação de biofilme dental, compostas por repetidas subunidades de proteína Flp1 (6,5 kDa), que representam o pili tipo IV de bactérias Gram-negativas (HENDERSON et al., 2003; KAPLAN; MEYENHORFER; FINE, 2003). Estudos genéticos e moleculares revelaram que o lócus de genes flp-rcp-tad é requerido para a produção de fímbrias, estando contido em uma ilha genômica composta de 14 genes arranjados em um operon (SCHREINER et al., 2003).

Sabe-se que cepas de $A$. actinomycetemcomitans recém-isoladas apresentam fímbrias, as quais são facilmente perdidas em laboratório, por meio de repiques sucessivos. Também, variantes lisas deste microrganismo apresentam adesinas fimbriais e não-fimbriais. Dentre as não-fimbriais se destaca a proteína Aae, que estimula a secreção do tipo V. Esta adesina Aae regula o processo de adesão às células epiteliais de primatas, incluindo o homem (FINE et al., 2005).

Sialidases bacterianas têm sido consideradas fatores de virulência em muitos organismos patogênicos que colonizam mucosas. São enzimas que catalisam a hidrólise de ácido siálico de glicoproteínas, glicolipídios e polissacarídeos, presentes na membrana celular. $O$ tratamento com sialidase expõe os receptores $\beta$-galactosil que participam da aderência de bactérias às mucosas do hospedeiro (SCHAUER, 1985).

A formação de biofilmes por bactérias patogênicas nas superfícies dos tecidos humanos tem se tornado objeto de interesse, pois bactérias no interior desses biofilmes são altamente resistentes aos antimicrobianos e antissépticos, capazes de escapar do sistema imune do hospedeiro. Essa resistência aumentada pode explicar porque infecções por $A$. actinomycetemcomitans não são facilmente erradicadas por terapia periodontal convencional (TAKAMATSU et al., 1999).

Aggregatibacter actinomycetemcomitans tem a capacidade de colonizar superfícies dentais formando populações agrupadas em biofilme, característica de bactérias periodontopatogênicas. Sabe-se que colônias rugosas de $A$. actinomycetemcomitans apresentam maior capacidade na formação de biofilme, 
assim como maior resistência às mudanças de salinidade e $\mathrm{pH}$. Essa capacidade é favorecida pela presença de fímbrias, que embora não sejam consideradas essenciais para o processo adesivo em algumas superfícies, aumentam as interações entre microrganismos e superfícies, colaborando desta maneira para a estabilização do biofilme (INOUE et al., 2003).

Aggregatibacter actinomycetemcomitans tem o potencial de invadir tecidos gengivais, localizando-se profundamente e ao longo da membrana basal. Esse processo invasivo fornece a este patógeno alguma proteção contra as defesas do hospedeiro (LI et al., 2004). Embora os mecanismos de invasão sejam intensamente estudados, os genes requeridos para esse processo estão ainda por serem identificados. Na literatura relata-se que o gene apaH estaria relacionado à invasibilidade do $A$. actinomycetemcomitans, codificando a produção da diadenosina tetrafosfatase que catalisa a quebra da alarmona diadenosina tetrafosfatase. Essas alarmonas são moléculas que regulam os sinais metabólicos em caso de estresse bacteriano (Ll et al., 2004).

Dentre os fatores de virulência produzidos pelo $A$. actinomycetemcomitans há dois deles com propriedades citolíticas que atuam contra as células humanas: a leucotoxina (Ltx) e a toxina distensora (Cdt). A leucotoxina é considerada o fator de virulência mais relevante dessa bactéria. Tsai et al. (1979), descreveram pela primeira vez a atividade leucotóxica das cepas de A. actinomycetemcomitans isoladas de lesão periodontal agressiva localizada, sendo também demonstrada sua capacidade de destruição das células fagocitárias humanas. Essa toxina é uma proteína de $116 \mathrm{kDa}$, pertencente à família das toxinas RTX (aminoácidos que se repetem na toxina), hidrossolúvel, se liga ao cálcio, e age formando poros na membrana celular das células-alvo.

Cepas leucotóxicas causam lise osmótica em leucócitos polimorfonucleares, monócitos, linfócitos e macrófagos de humanos e de outros primatas (ZADEH et al., 1999). Essa toxina também induz em células T, células $B$ e células HL-60 a morte por apoptose (KOROSTOFF et al., 1998).

A produção da leucotoxina é codificada por um operon composto por quatro genes, Itx $C$, It $x A$, It $x B$ e Itx $D$. O gene ItxA é o responsável por codificar a estrutura da toxina e os outros três genes parecem ser necessários para ativação e secreção da mesma. $O$ gene Itx $C$ pode codificar uma proteína carreadora envolvida na acilação da leucotoxina, enquanto que ItxB e ItxD estão envolvidos no transporte da toxina e 
na sua inserção na membrana (BROGAN et al., 1994). De acordo com a toxicidade, cepas de $A$. actinomycetemcomitans altamente leucotóxicas possuem deleção de 530 bp no promotor LTX, ao passo que, as minimamente leucotóxicas não a possuem (ZAMBON et al., 1996).

A toxina distensora é a mais recente proteína termolábil e foi descrita por Johnson e Lior (1987). O fator de distensão age produzindo mudanças morfológicas, que progressivamente, podem levar à morte celular. Dessa forma, observa-se o crescimento da célula, que se distende até cinco vezes seu tamanho original, com arredondamento e a cromatina irregularmente condensada com fragmentação nuclear. Esse fator também provoca nas células eucarióticas um bloqueio na fase G2 do ciclo celular, dividido em quatro fases sucessivas: G1, S, G2 e M. A fase G2 é o período compreendido entre o final da síntese de DNA e o início da mitose (PICKETT; WHITEHOUSE, 1999).

Além de interromper a fase G2 do ciclo celular, o fator de distensão possui ainda capacidade de induzir apoptose. Shenker et al. (2001) relataram que linfócitos humanos se tornaram apoptóticos após exposição a um extrato que continha os três peptídeos de Cdt ou uma preparação altamente purificada de CdtB. Sua atividade tem sido frequentemente demonstrada em células HeLa, HEp-2, KB, Vero, CHO, linfócitos $T$ humanos, como também, em fibroblastos gengivais humanos e células do ligamento periodontal (BELIBASAKIS et al., 2004).

As proteínas CdtA e CdtC formam a subunidade responsável pelo transporte de CdtB (subunidade ativa da toxina), que levado ao núcleo das células do hospedeiro, causa danos ao DNA por exibir uma sequência limitada de aminoácidos similar à da família das proteínas DNAse I (LARA-TEJERO; GALÁN, 2000). 


\section{OBJETIVOS}

O presente estudo teve como objetivos:

1. Analisar a ocorrência de $A$. actinomycetemcomitans em indivíduos com periodontite crônica e agressiva, e sem doença periodontal;

2. Avaliar as características fenotípicas dos isolados nos processos de adesão, invasão e citotoxicidade às células epiteliais bucais;

3. Detectar a presença dos genes relacionados aos processos de adesão (flp-1), invasão $(a p a H)$ e citotoxicidade (promotor-LTX, ItxA, $c d t A, c d t B, c d t C$ e $c d t A B C$ ), determinando sua prevalência na população estudada. 


\section{MATERIAIS E MÉTODOS}

\subsection{Seleção de Pacientes}

Os pacientes foram selecionados nas Clínicas de Periodontia por especialista em Periodontia previamente treinado, pertencente ao Departamento de Estomatologia - FOUSP. As informações relativas à condição de saúde geral e bucal dos pacientes foram obtidas por meio de anamnese e pela realização de exames extra e intra oral. Além disso, os pacientes foram submetidos a exame radiográfico periapical completo, análise do índice de placa bacteriana, índice de sangramento e profundidade clínica de sondagem.

Após a avaliação clínica periodontal, estes foram classificados em dois grupos com base nos critérios de Armitage (1999): Grupo I, composto por 65 pacientes portadores de doença periodontal, com idades de 20 a 50 anos, sendo 30 do sexo feminino e 35 do sexo masculino. Dentre estes, 31 pacientes apresentaram periodontite crônica (com inflamação e cálculo subgengival, recessão gengival, progressiva perda óssea e de inserção, e bolsas periodontais com profundidade $\geq 6$ $\mathrm{mm}$ ), e 34 pacientes apresentaram periodontite agressiva (com rápida perda de inserção e destruição óssea, histórico familiar, e clinicamente saudável). Grupo II, composto por 48 indivíduos saudáveis (com ausência de sinais de inflamação e sangramento gengival, e profundidade de sondagem $\leq 3 \mathrm{~mm}$ ), com idades de 20 a 45 anos, sendo 18 do sexo feminino e 30 do sexo masculino.

Foram excluídos deste trabalho os pacientes que utilizaram antibióticos nos três meses anteriores à data da coleta, sofriam de qualquer doença sistêmica e estavam grávidas. Todos os participantes assinaram um Termo de Consentimento Livre e Esclarecido, e este estudo foi aprovado pelo Comitê de Ética em Pesquisa com Seres Humanos, do ICB - USP (Processo No. 662/CEP).

\subsection{Coleta de Amostras Clínicas}

Inicialmente, o biofilme supragengival do elemento dentário (incisivos e molares) foi removido por meio de gaze esterilizada e a seguir, as amostras subgengivais foram coletadas com auxílio de dois cones de papel absorvente esterilizados no. 40 (Endopoints Ltda., Rio de Janeiro, R.J., Brasil), inseridos na 
região mais apical possível do sulco gengival sadio ou da bolsa periodontal, sendo mantidos por 60 segundos. Em seguida, os cones foram transferidos para tubos contendo $3 \mathrm{ml}$ de meio de transporte VMGA III (viability maintaining microbiostatic medium) (MÖLLER, 1966). Todas as amostras foram processadas em até 2 horas após a coleta.

\subsection{Isolamento e Identificação Bacteriana}

As amostras foram homogeneizadas por agitação em vórtex (Fanem, São Paulo, S.P., Brasil) procedendo-se, a seguir, às diluições seriadas em solução VMGA I. Alíquotas de $0,1 \mathrm{ml}$ de diluições pré-estabelecidas $\left(10^{-1}, 10^{-2}, 10^{-3}\right)$ foram transferidas, em duplicata, para placas com meio seletivo ágar soja tripticaseína com soro inativado de cavalo, bacitracina e vancomicina (TSBV) (SLOTS, 1982). As placas foram incubadas a $37^{\circ} \mathrm{C}$, por 72 horas, em anaerobiose $\left(90 \% \mathrm{~N}_{2}, 10 \% \mathrm{CO}_{2}\right)$. A identificação inicial de $A$. actinomycetemcomitans foi realizada com microscópio estereoscópico, observando-se colônias características de $1 \mathrm{~mm}$ de diâmetro, aspecto interno em forma de estrela ou charutos cruzados, com margens ligeiramente irregulares.

A seguir, foram cultivadas de uma a três colônias características de cada amostra subgengival em ágar sangue Brucella, suplementado com $0.5 \%$ de extrato de levedura, $5 \mathrm{mg} / \mathrm{mL}$ de hemina e $1 \mathrm{mg} / \mathrm{mL}$ de menadiona. $E$ então, identificadas por coloração de Gram, produção de catalase, susceptibilidade ao $\mathrm{NaF}$ e testes bioquímicos de fermentação de glicose, frutose e manose, e de não-fermentação de lactose, amido, sacarose ou trealose (SLOTS; REYNOLDS; GENCO, 1980). Todos os isolados de $A$. actinomycetemcomitans foram estocados a $-80{ }^{\circ} \mathrm{C}$ em leite desnatado a 10\% (Difco Laboratories, U.K., England).

\subsection{Biotipagem}

Todos os isolados foram biotipados com base na fermentação variável de dextrina, maltose, manitol e xilose (SLOTS; REYNOLDS; GENCO, 1980). 


\subsection{Caracterização Fenotípica de Alguns Fatores de Virulência}

\subsubsection{Ensaio de Adesão às Células Orais}

Ensaios de adesão usando células KB (células de carcinoma epidermóide oral humano) foram realizados como descrito previamente (CRAVIOTO et al., 1979; NAKANO et al., 2008). Brevemente, $1.0 \times 10^{5}$ células KB foram cultivadas em $960 \mu \mathrm{L}$ de meio RPMI 1640 (Cultilab Ltda., Campinas, S.P., Brasil) com soro fetal bovino ( $2 \% \mathrm{v} / \mathrm{v})$ em placas 24-poços. Essas células foram inoculadas com $40 \mu \mathrm{L}$ de cultura bacteriana $\left(1.5 \times 10^{8}\right.$ células $\left./ \mathrm{mL}\right)$. As placas foram incubadas $\left(5 \mathrm{~h} \mathrm{em} 5 \% \mathrm{CO}_{2}\right)$, lavadas três vezes com 0.1 M PBS (phosphate-buffered saline), (136 mM NaCl, 2.7 $\mathrm{mM} \mathrm{KCl}, 8.1 \mathrm{mM} \mathrm{Na}_{2} \mathrm{HPO}_{4}, 1.5 \mathrm{mM} \mathrm{KH}_{2} \mathrm{PO}_{4}, \mathrm{pH} 7.4$ ), fixadas (metanol absoluto) e coradas com corante May-Grünwald-Giemsa. A cepa enteropatogênica Escherichia coli O127:H6 (E2348/69) que apresenta padrão de adesão localizado foi usada como controle positivo. Todos os testes foram realizados em duplicata.

\subsubsection{Avaliação da Invasão às Células Orais}

Testes de invasão foram realizados como descrito por Nakagawa et al. (2002), com modificações. Alíquota de $100 \mu \mathrm{L}$ de uma cultura bacteriana de $24 \mathrm{~h}$ com $1.5 \mathrm{x}$ $10^{8}$ células $/ \mathrm{mL}$ foi adicionada a $1.0 \times 10^{5}$ células $\mathrm{KB}$ e então, incubada $(2 \mathrm{~h}$ em $5 \%$ $\mathrm{CO}_{2}$ ). Bactérias não aderentes foram eliminadas por incubação (1 h em $5 \% \mathrm{CO}_{2}$, a $37 \stackrel{\circ}{\circ}$ ) em $1 \mathrm{~mL}$ de meio de Eagle modificado, de Dulbecco (DMEM) contendo $2 \%$ de soro fetal bovino com $300 \mu \mathrm{g} / \mathrm{mL}$ de gentamicina. Então, células foram lavadas três vezes em PBS e lisadas com $400 \mu \mathrm{L}$ de Triton-X-100 (1\%, v/v). Após a mistura, 100 $\mu \mathrm{L}$ foram plaqueados em ágar sangue Brucella (Difco Laboratories, U.K.), incubadas em anaerobiose a $37^{\circ} \mathrm{C}$ por $48 \mathrm{~h}$, e as UFC foram determinadas. A cepa de $E$. coli enteroinvasiva sorotipo 0124:NM, e a não invasiva E. coli HB101 foram, respectivamente, usadas como controles positivo e negativo. Todos os testes foram realizados em duplicata. A invasão foi expressa como a porcentagem de bactérias recuperadas do inóculo inicial após tratamento com antibiótico e lise das células epiteliais, de acordo com Tang et al. (1993). 


\subsubsection{Ensaio de Citotoxicidade às Células Orais}

Citotoxicidade bacteriana foi testada em monocamada de cultura de células KB, segundo Gaetti-Jardim et al. (2008). Células KB foram cultivadas em placa de microtitulação 96-poços (Corning Life Sciences, California, U.S.A.) com meio mínimo L15 (Cultilab Ltda.), sendo adicionado $2 \%$ soro fetal bovino e incubadas em atmosfera de $5 \% \mathrm{CO}_{2}$, a $37{ }^{\circ} \mathrm{C}$ por $48 \mathrm{~h}$. Isolados de A. actinomycetemcomitans foram crescidos em BHI, e então, centrifugados (13,000 g, 5 min). Sobrenadantes foram filtrados em filtros de membrana de $0.45 \mu \mathrm{m}$ (Millipore Corp., MA, U.S.A.), e $50 \mu \mathrm{L}$ foram adicionados em duplicata às células KB. Após $4 \mathrm{~h}$ de incubação (5\% $\mathrm{CO}_{2}$, a $37^{\circ} \mathrm{C}$ ), os resultados foram comparados com as células sem sobrenadante bacteriano (controle negativo). A citotoxicidade foi considerada quando a presença de células alteradas foi detectada. A cepa $A$. actinomycetemcomitans JP2, altamente citotóxica, foi usada como controle positivo.

\subsubsection{Detecção de Neuraminidase}

A produção de neuraminidase foi determinada usando eritrócitos humanos normais doados por voluntários saudáveis, como descrito por Nakano, Piazza e Avila-Campos (2006). Os eritrócitos foram coletados em solução Alsever (10\%), lavados três vezes em $0.01 \mathrm{M}$ de $\mathrm{PBS}\left(\mathrm{Na}_{2} \mathrm{HPO}_{4}, \mathrm{KH}_{2} \mathrm{PO}_{4}, \mathrm{NaCl}, \mathrm{pH}\right.$ 7.4) e mantidos a $4{ }^{\circ} \mathrm{C}$ durante uma semana. A. actinomycetemcomitans crescidos em caldo $\mathrm{BHI}$ foram ressuspendidos a $1.5 \times 10^{8}$ bactérias $/ \mathrm{mL}$. A suspensão bacteriana foi lavada três vezes por centrifugação $(12,000 \mathrm{~g}, 10 \mathrm{~min})$. Então, $1 \mathrm{~mL}$ de bactérias foi adicionado à $10 \mu \mathrm{L}$ de eritrócitos lavados, atingindo a concentração final de $1 \%$, cuidadosamente homogeneizada e incubada em anaerobiose a $37^{\circ} \mathrm{C}$ por $4 \mathrm{~h}$. Em placas de 96-poços, foram realizadas diluições seriadas de lectina de amendoim (2.5 $\mu \mathrm{g} / \mu \mathrm{L})$ (Arachis hypogaea, PNA, Sigma Chemical Co.) em PBS e $20 \mu \mathrm{L}$ de cada diluição foram adicionados à mistura bactéria-eritrócitos. As placas foram homogeneizadas e incubadas a temperatura ambiente por $1 \mathrm{~h}$, seguindo-se de incubação adicional a $4{ }^{\circ} \mathrm{C}$ overnight. A presença de neuraminidase foi notada quando uma aglutinação (bactéria-eritrócitos-lectina) foi observada. A mistura de bactéria-eritrócitos sem lectina foi usada como controle negativo (precipitação). A cepa Porphyromonas gingivalis ATCC 33277 foi usada como controle positivo. O 
título de aglutinação foi definido como o recíproco do ponto final de diluição.

\subsubsection{Inibição da Atividade da Enzima Neuraminidase}

A inibição da produção de neuraminidase foi verificada nos isolados neuraminidase-positivos conforme Nakano, Piazza e Avila-Campos (2006). Brevemente, bactérias foram tratadas com $1 \mathrm{~mL}$ de $1 \mathrm{mM}$ de galactose e incubadas à temperatura ambiente, por $30 \mathrm{~min}$. Em placas de microtitulação, $2 \mu \mathrm{L}$ de lectina diluída foram misturados com $18 \mu \mathrm{L}$ de bactérias tratadas com $1 \mathrm{mM}$ de galactose e adicionados $20 \mu \mathrm{L}$ de eritrócitos a $1 \%$. As placas foram levemente homogeneizadas, incubadas a $37^{\circ} \mathrm{C}$ por $1 \mathrm{~h}$, e a inibição da enzima foi notada pela precipitação dos eritrócitos. A mistura de bactéria-eritrócitos-lectina foi usada como controle negativo.

\subsubsection{Ensaio da Formação de Biofilme}

A formação de biofilme foi quantificada por meio do ensaio de ligação ao cristal violeta, como descrito previamente por Kaplan, Meyenhorfer e Fine (2003). Dos isolados de $A$. actinomycetemcomitans crescidos em caldo $\mathrm{BHI}, 100 \mu \mathrm{L}$ foram inoculados em placas de 24-poços, com e sem lamínulas de vidro circulares $(13 \mathrm{~mm}$ de diâmetro), contendo $1000 \mu \mathrm{L}$ de meio DMEM (4-5 g de glicose sem antibiótico) (Cultilab Ltda.) em uma diluição de 1:10 do inóculo bacteriano. Após $48 \mathrm{~h}$ de incubação a $37{ }^{\circ} \mathrm{C}$, em atmosfera de $5 \% \mathrm{CO}_{2}$, o meio contendo células não aderidas foi removido. Biofilmes foram lavados três vezes com 1X PBS para remover as células fracamente aderidas, fixados com etanol 75\% por $10 \mathrm{~min}$ (1 $\mathrm{mL}$ por poço), e corados com cristal violeta $0,5 \%$ por $5 \mathrm{~min}$. $O$ corante ligado ao biofilme foi extraído com $1 \mathrm{~mL}$ de etanol 95\% por 2 min, e a absorbância da solução de cristal violeta foi medida usando leitor de placa de microtitulação (BioRad Benchmark, Califórnia, U.S.A.), ajustado a $A_{595} \mathrm{~nm}$. Todos os testes foram realizados em triplicata. Foram utilizados como controle positivo E. coli O42 e como controle negativo E. coli DH5a.

\subsubsection{Detecção de Cápsula e Fímbrias}

Cápsulas foram detectadas por coloração de Hiss com modificações 
(NAKANO; AVILA-CAMPOS, 2004). Uma gota de suspensão bacteriana, de uma cultura em peptona-extrato de levedura com $1 \%$ de glicose, foi depositada em uma lâmina de microscópio, coberta com cristal violeta e aquecida até a emissão de vapores. Cada lâmina foi lavada com sulfato de cobre a $20 \%$ e secas à temperatura ambiente. Cápsulas foram identificadas sob microscopia de luz como áreas claras ao redor da bactéria. A presença de fímbrias foi investigada por coloração negativa com ácido fosfotúngstico (2\%) e acetato de uranila (2\%), e examinadas com um MET Zeiss EM-109 operado a $80 \mathrm{kV}$ (NAKANO et al., 2008).

\subsection{Caracterização Molecular}

\subsubsection{Extração de DNA Bacteriano}

DNA de $A$. actinomycetemcomitans foi extraído pelo método de fenolclorofórmio, segundo Avila-Campos et al. (1999). Células bacterianas crescidas em caldo $\mathrm{BHI}$ foram coletadas e lisadas com sacarose $20 \%, 1,4 \mathrm{M} \mathrm{Na} 2 \mathrm{PO}_{4}$ e $10 \mathrm{mg} / \mathrm{mL}$ de lisozima, e incubadas a $37 \stackrel{\circ}{\circ}$ por 15 min. O lisado foi misturado com 0,5 M Tris $\mathrm{HCl}, 0,5 \mathrm{M} \mathrm{EDTA}, 10 \mathrm{mg} / \mathrm{mL}$ proteinase $\mathrm{K}$ e SDS 25\%. O DNA foi extraído com fenol, perclorato de sódio e clorofórmio, e após centrifugação $(5,000 \times \mathrm{g}, 5 \mathrm{~min})$ foi precipitado com etanol gelado. O DNA foi resuspendido em $150 \mu \mathrm{L}$ de TE esterilizado e estocado a $-80^{\circ} \mathrm{C}$ até seu uso.

\subsubsection{Detecção dos Genes flp-1 (adesão), apaH (invasão), Itx (leucotoxina) e cdt (toxina distensora) por Reação em Cadeia da Polimerase (PCR)}

Os ensaios de PCR foram realizados usando pares de iniciadores específicos (Tabela 1). As reações de amplificação foram realizadas em volumes finais de $25 \mu \mathrm{l}$, contendo 8,25 $\mu \mathrm{l}$ de água ultra-pura esterilizada, 2,5 $\mu \mathrm{l}$ de $10 \times$ tampão PCR, $1 \mu \mathrm{l}$ de $\mathrm{MgCl}_{2}(50 \mathrm{mM}), 1 \mu \mathrm{l}$ de dNTP $(0,2 \mathrm{mM}), 1 \mu \mathrm{l}$ de cada iniciador $(0,4 \mu \mathrm{M}), 0.25 \mu \mathrm{l}$ de Taq DNA polimerase $(0,5 \mathrm{U})$ e $10 \mu \mathrm{l}$ de DNA. A amplificação do DNA foi realizada em termociclador (Perkin Elmer, GeneAmp PCR System 9700), programado para: 1 ciclo de $94^{\circ} \mathrm{C}$ (5 min.), 30 ciclos de $94^{\circ} \mathrm{C}\left(1 \mathrm{~min}\right.$.), $50^{\circ} \mathrm{C}$ a $65^{\circ} \mathrm{C}$ ( $1 \mathrm{~min}$.), $72^{\circ} \mathrm{C}(1 \mathrm{~min}$.), e 1 ciclo de $72{ }^{\circ} \mathrm{C}$ (5 min.) para a extensão final do DNA (Tabela 1). Como controle negativo, foi utilizada água ultra-pura ao invés de DNA bacteriano. 
Os produtos de PCR foram analisados por eletroforese em gel de agarose a $1 \%$, corados com brometo de etídio $(0,5 \mu \mathrm{g} / \mathrm{ml})$ e fotografados sob transiluminador com luz UV com o sistema Kodak (Electrophoresis Documentation and Analysis System 120, Kodak Digital Science). O marcador $1 \mathrm{~kb}$ DNA ladder (Invitrogen do Brasil, São Paulo, S.P.) serviu como padrão de peso molecular.

\subsection{Análise Estatística}

Todas as análises estatísticas foram realizadas com o programa GraphPad InStat (versão 3.05, Graphpad Software, San Diego, CA, USA). Os dados foram calculados de dois experimentos e analisados por Qui-quadrado e Teste exato de Fisher. Um $p<0,05$ foi considerado significante. 
Tabela 1 - Oligonucleotídeos, temperatura de anelamento e tamanho dos amplicons usados na detecção de genes

\begin{tabular}{|c|c|c|c|c|}
\hline Genes & Oligonucleotídeos $\left(5^{\prime} \rightarrow 3^{\prime}\right)$ & $\begin{array}{c}\mathrm{T}^{\circ} \\
\text { anelamento } \\
\left({ }^{\circ} \mathrm{C}\right)\end{array}$ & $\begin{array}{l}\text { Amplicon } \\
\text { (bp) }\end{array}$ & Referência \\
\hline \multirow[t]{2}{*}{ flp1 } & AAC AAC AAT AGG AGC ATT AAG ACA & 55 & 300 & Kachlany et al. (2001) \\
\hline & GTA TTT AAT ATT TAA GTT GTT ACT TATT & & & \\
\hline \multirow[t]{2}{*}{ apaH } & ATT TAA TCG GCG ACC TGC AC & 52 & 825 & Dogan et al. (1999) \\
\hline & TGT CTT CCC AAC GTA GCA TG & & & \\
\hline \multirow[t]{2}{*}{$c d t A$} & GGT TTA GTG GCT TGT & 50 & 583 & Fabris et al. (2002) \\
\hline & CAC GTA ATG GTT CTG TT & & & \\
\hline \multirow[t]{2}{*}{$c d t B$} & GGT TTT CTG TAC GAT GT & 50 & 790 & Fabris et al. (2002) \\
\hline & GGA TGT AAT TTG TGA GCG T & & & \\
\hline \multirow[t]{2}{*}{$c d t C$} & GAC TTT GAC GAG TCA TGC A & 50 & 512 & Fabris et al. (2002) \\
\hline & СCT GAT TTC TCC CCA & & & \\
\hline \multirow[t]{2}{*}{$c d t A B C$} & GGT TTA GTG GCT TGT & 50 & 2065 & Fabris et al. (2002) \\
\hline & CCT GAT TTC TCC CCA & & & \\
\hline \multirow[t]{2}{*}{ ItxA } & TCG CGA ATC AGC TCG CCG & 65 & 285 & Tan et al. (2002) \\
\hline & GCT TTG CAA GCT CCT CAC C & & & \\
\hline LTX & GCA GGA TCC ATA TTA AAT CTC CTT GT & 55 & $492^{*}$ & Cortelli et al. (2003) \\
\hline (promotor) & GCG GTC GAC AAC CTG ATA ACA GTA TT & & $1022^{\star *}$ & \\
\hline
\end{tabular}

*Cepa altamente leucotóxica;

${ }^{\star *}$ Cepa minimamente leucotóxica 


\section{RESULTADOS}

Neste estudo foram avaliados 65 pacientes com doença periodontal, sendo que 31 deles apresentaram periodontite crônica e 34 periodontite agressiva. Como observado na Tabela 2, dos pacientes com periodontite crônica, 17 (54,8\%) apresentaram $A$. actinomycetemcomitans e dos 34 pacientes com periodontite agressiva somente seis $(17,6 \%)$ foram positivos para esse microrganismo. Como neste estudo de cada amostra clínica positiva foram cultivadas de uma a três colônias, foram isoladas 70 bactérias. Dos 48 pacientes sadios, somente um deles abrigou $A$. actinomycetemcomitans, obtendo-se três isolados. Também, é importante notar que a faixa de profundidade de sondagem variou de 6 a $13 \mathrm{~mm}$ para os pacientes com doença periodontal e de 1 a $3 \mathrm{~mm}$ para os indivíduos sadios.

Tabela 2 - Características clínicas dos pacientes com doença periodontal e dos pacientes sadios, com amostras positivas para $A$. actinomycetemcomitans

\begin{tabular}{|c|c|c|c|c|c|c|}
\hline Condição periodontal & & & $\begin{array}{l}\text { Média } \\
\text { Idade }\end{array}$ & Faixa profundidade & Pacientes positivos & No. \\
\hline (No.) & M & $\mathrm{F}$ & (anos) & sondagem & bactéria & isolados \\
\hline Periodontite crônica (31) & 19 & 12 & 43,5 & 6 a $13 \mathrm{~mm}$ & 17 & 35 \\
\hline Periodontite agressiva (34) & 16 & 18 & 22,5 & 6 a $9 \mathrm{~mm}$ & 6 & 35 \\
\hline Periodonto saudável (48) & 30 & 18 & 26,5 & 1 a $3 \mathrm{~mm}$ & 1 & 3 \\
\hline
\end{tabular}

Dos 70 A. actinomycetemcomitans isolados de pacientes com doença periodontal, 45 deles pertenceram ao biotipo II; 9 ao biotipo X; 5 ao biotipo $\mathrm{VI} ; 5$ ao biotipo VIII; 3 ao biotipo IX; 1 ao biotipo I; 1 ao biotipo III e 1 ao biotipo V. Da mesma forma, dos três isolados de indivíduo sadio, 2 pertenceram ao biotipo II e 1 ao biotipo $\mathrm{X}$.

Sessenta e quatro $(91,4 \%)$ dos 70 isolados de periodontite e dois dos três isolados de indivíduo sadio mostraram capacidade adesiva às células KB. Esses valores mostraram diferenças estatisticamente significantes $(p=0,002)$; (Tabela 3 ). $\mathrm{Na}$ Figura 1, podem ser observados isolados de $A$. actinomycetemcomitans aderidos 
às células $K B$, formando pequenos grupos não localizados em relação à cepa controle E. coli O 127: H6 (E2348/69) que apresentou um padrão localizado.

Tabela 3 - Adesão e invasão às células KB de $A$. actinomycetemcomitans isolados de pacientes com periodontite e de indivíduos sadios

\begin{tabular}{llll}
\hline Isolados & Adesão & Invasão & $\mathrm{UFC} / \mathrm{ml}\left(10^{3}\right)$ \\
(No.) & No. $\%$ & No. $\%$ & média \\
\hline
\end{tabular}

Pacientes periodontite

$\begin{array}{lllll}64 & 91.4 & 32 & 50 & 0.2 \text { to } 1.4\end{array}$

Indivíduos sadios

$$
2 \quad 66.6
$$

150

0.1 to 10

Figura 1 - Padrão de adesão de A. actinomycetemcomitans (a) e E. coli O127:H6 (E2348/69) (enteropatogênica) (b) às celulas orais KB
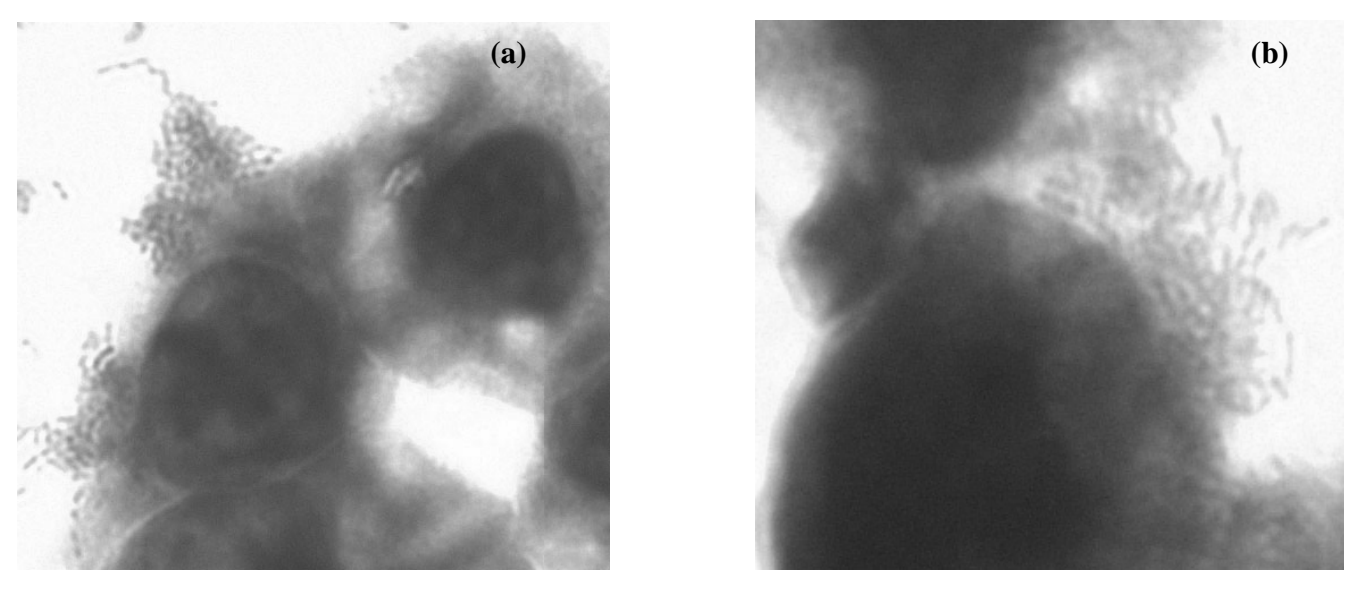

Das 64 bactérias isoladas de pacientes com periodontite que mostraram capacidade de adesão às células KB, $32(50 \%)$ mostraram capacidade de invadir, como observado na Tabela 3. Também, dos dois isolados de indivíduo sadio, somente um foi capaz de invadir as células $K B$. Os isolados não aderentes não foram capazes de invadir as células $\mathrm{KB}$. Assim, a maioria dos $A$. actinomycetemcomitans isolados de periodontite foram capazes de invadir as células $K B$, mas nenhuma diferença estatisticamente significante foi observada $(p=0,110)$.

Quarenta e quatro $(62,8 \%)$ dos 70 isolados de pacientes com periodontite, e dois isolados de indivíduo sadio, mostraram-se citotóxicos para as células KB, 
produzindo alongamento celular e em alguns casos, ligeiro aumento do tamanho da célula KB.

A produção da enzima neuraminidase foi observada em 60 (82,2\%) dos 73 isolados de $A$. actinomycetemcomitans, apresentando títulos de aglutinação com valores entre 2 e 8 . Não foram observadas diferenças quanto à produção dessa enzima entre os isolados de ambos os grupos de pacientes com periodontite crônica e agressiva. Também, a produção dessa enzima foi inibida pela presença de galactose em todos os isolados.

Pelo ensaio da formação de biofilme in vitro, $52(74,3 \%)$ isolados de pacientes com periodontite mostraram essa capacidade, tanto nos substratos de vidro como no de plástico, com valores de 0,5 a > 3. Também, 18 (25,7\%) produziram biofilmes com valores de $<0,1$ a 0,4 . Não foi observada alguma diferença na formação de biofilme entre os isolados de ambas as origens, isto é, de periodontite crônica e agressiva. Dois dos três isolados de paciente sadio mostraram capacidade de formar biofilmes.

A presença de cápsula foi observada em todos os isolados de pacientes com periodontite e de indivíduo sadio pela utilização de microscópio óptico, e por Microscopia Eletrônica de Transmissão essa estrutura foi observada como uma camada elétron-densa. Também, em nenhum dos isolados foram observadas estruturas semelhantes às fímbrias e sim, vesículas sobre a superfície bacteriana.

Os genes apaH (associado à invasão) e flp-1 (associado às fímbrias) foram detectados, respectivamente, em $51(72,9 \%)$ e 38 (54,3\%) dos isolados obtidos de pacientes com periodontite, e em um e dois isolados de indivíduo sadio.

Com relação à atividade leucotóxica, foi observado que dos 70 isolados de pacientes com periodontite, todos eles abrigaram o promotor LTX da leucotoxina, sendo $64(91,4 \%)$ considerados como grandes produtores dessa toxina e que apresentaram a deleção cromossômica produzindo bandas de 492 bp. Seis isolados foram considerados como fracamente produtores, produzindo bandas de $1022 \mathrm{bp}$. Os três isolados de paciente sadio foram considerados como fracamente produtores de leucotoxina. O gene ItxA foi observado em todos os isolados testados (Tabela 4). 
Tabela 4 - Presença de genes em A. actinomycetemcomitans isolados de pacientes com periodontite e de indivíduos sadios

\begin{tabular}{|c|c|c|c|c|c|c|c|c|}
\hline \multirow{3}{*}{$\begin{array}{l}\text { Isolados } \\
\text { No. }\end{array}$} & \multicolumn{8}{|c|}{ No. de isolados abrigando genes } \\
\hline & LTX & ItxA & $c d t A$ & $c d t B$ & $c d t C$ & $c d t A B C$ & apaH & $f \mid p-1$ \\
\hline & Promotor $^{1}$ & & & & & & & \\
\hline \multirow{2}{*}{ Periodontite (70) } & $64^{*}$ & 64 & 50 & 48 & 60 & 40 & 51 & 38 \\
\hline & $6^{* *}$ & 6 & 0 & 0 & 0 & 0 & 0 & 0 \\
\hline Sadios (3) & $3^{* *}$ & 3 & 0 & 0 & 1 & 0 & 1 & 2 \\
\hline Cepa JP2** & + & + & + & + & + & + & + & + \\
\hline
\end{tabular}

${ }^{1}$ Promotor leucotoxina

${ }^{*}$ Cepas altamente leucotóxicas (492 bp)

${ }^{*}$ Cepas minimamente leucotóxicas (1,022 bp)

Também, 50 isolados $(71,4 \%)$ abrigaram o gene cdtA, 48 (68,6\%) o gene $c d t B, 60(85,7 \%)$ o gene $c d t C$ e $40(57,1 \%)$ o gene $c d t A B C$. Os três isolados de indivíduo sadio abrigaram o gene $\operatorname{Itx} A$ e um deles o gene cdtC (Figura 2). Foi observado que a maioria dos isolados produziram um dos quatro genes relacionados à produção da toxina distensora. É interessante notar que os isolados negativos para alguns dos genes da toxina distensiva abrigaram o gene ItxA e o promotor LTX. 
Figura 2 - Detecção de genes apaH (a), flp1 (b), cdtA (c), cdtB (d), cdtC (e), cdtABC (f), ItxA (g) e promotor LTX (h) em A. actinomycetemcomitans
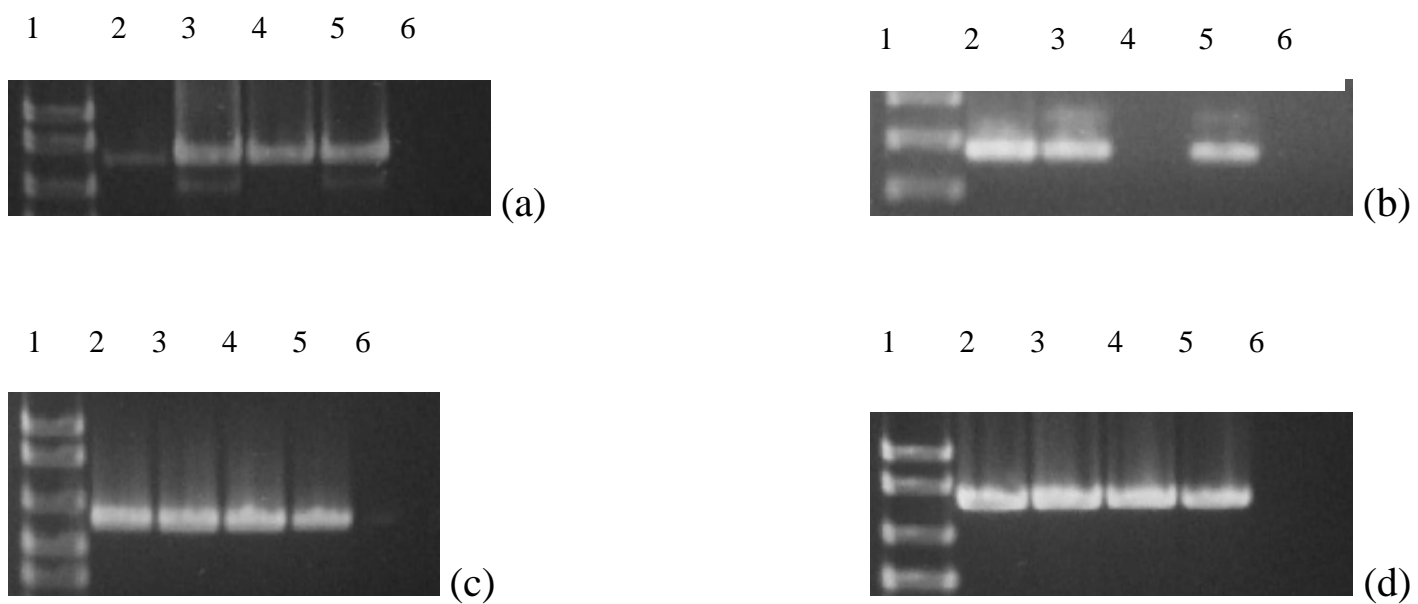

$\begin{array}{lllllll}1 & 2 & 3 & 4 & 5 & 6 & 7\end{array}$
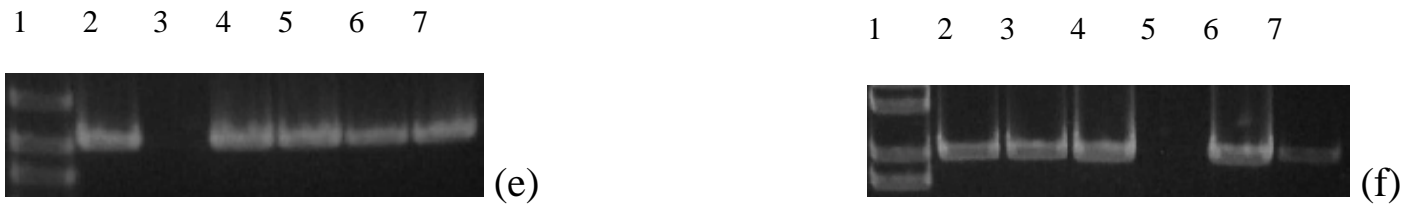

(e)

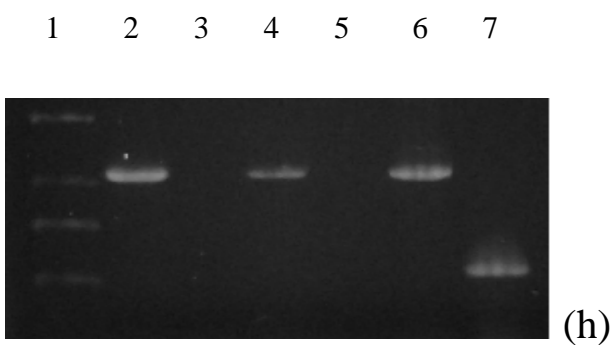




\section{DISCUSSÃo}

Aggregatibacter actinomycetemcomitans tem sido fortemente implicado no desenvolvimento de periodontite em pacientes jovens, particularmente no que diz respeito à periodontite agressiva (ASIKAINEN et al., 1997). A literatura tem relatado que este microrganismo é o agente causador desse tipo de periodontite.

A agressividade desta bactéria é determinada pela produção de vários fatores de virulência, os quais estão envolvidos na colonização da cavidade oral, na destruição dos tecidos periodontais e na interferência sobre os mecanismos de defesa do hospedeiro (WILSON; HENDERSON, 1995). Como é observado na Tabela 2, a média de idade dos pacientes com periodontite agressiva foi de 22,5 anos e dos pacientes com periodontite crônica de 43,5 anos, o que confirma a prevalência da forma agressiva em pacientes jovens, embora a positividade para a presença de $A$. actinomycetemcomitans tenha sido maior nos pacientes com periodontite crônica.

Em nosso estudo, A. actinomycetemcomitans foi detectado em $54,8 \%$ dos pacientes com periodontite crônica e em $17,6 \%$ dos pacientes com periodontite agressiva, resultado semelhante ao obtido por Gajardo et al. (2005) que analisou a presença desse microrganismo em indivíduos chilenos com periodontite crônica, observando maior prevalência de $A$. actinomycetemcomitans neste grupo em relação aos indivíduos com periodontite agressiva, 35,3\% e 19,4\%, respectivamente. Contudo, alguns trabalhos nacionais mostraram resultados diferentes dos observados neste estudo, encontrando maior prevalência de $A$. actinomycetemcomitans em pacientes com periodontite agressiva e menor prevalência em pacientes com periodontite crônica (CORTELLI et al., 2005; JARDIM-JUNIOR et al., 2006).

Tal divergência nos resultados pode ser explicada pela diversidade racial, étnica e cultural encontrada na população brasileira, pelas características particulares de cada indivíduo como hábitos e costumes, assim como pela diferença entre as metodologias de estudo adotadas. Mombelli, Casagni e Madianos (2002) demonstraram que a presença ou ausência de $A$. actinomycetemcomitans não poderia distinguir pacientes com periodontite agressiva daqueles com periodontite crônica, mas a infecção por $A$. actinomycetemcomitans altamente leucotóxico estaria intimamente associada com a periodontite agressiva. 
Com relação aos indivíduos saudáveis, $A$. actinomycetemcomitans foi detectado em $2 \%$, o que está de acordo com o observado por Malheiros e AvilaCampos (2004). Convém lembrar que, a maioria dos estudos mostra uma pequena frequência de isolamento dessa bactéria em indivíduos sadios. Meng et al. (2009) demonstraram que a prevalência de $A$. actinomycetemcomitans nos sítios com periodontite foram significativamente maiores que nos sítios sadios, o que também foi constatado nesse estudo.

Em geral, a literatura relata que existe uma relação significativa entre a colonização por $A$. actinomycetemcomitans e a profundidade da bolsa periodontal, então, a taxa de isolamento da bactéria seria maior nos indivíduos que possuem profundidade de bolsa $>5 \mathrm{~mm}$ (YANO-HIGUCHI et al., 2000). Como se observa na Tabela 2, a faixa de profundidade de sondagem para os pacientes com doença periodontal variou de 6 a $13 \mathrm{~mm}$, e para os indivíduos sadios, de 1 a $3 \mathrm{~mm}$, o que explica a maior taxa de isolamento de $A$. actinomycetemcomitans de indivíduos com periodontite, quando comparada à taxa de isolamento de pacientes sadios, indicando também a natureza microaerofílica dessa bactéria.

Estudos têm mostrado que $A$. actinomycetemcomitans é frequentemente encontrado em pessoas com descendência africana e que o clone JP2, altamente leucotóxico, parece ser originário de indivíduos africanos (HAUBEK et al., 1997). Certamente, uma população como a brasileira com elevada proporção de pessoas de origem africana teria a tendência de apresentar uma elevada prevalência de $A$. actinomycetemcomitans, assim como, de A. actinomycetemcomitans altamente leucotóxico, quando comparada às populações com baixas proporções de descendentes de africanos. Neste estudo, a maioria dos isolados de periodontite foram considerados como altamente leucotóxicos, enquanto que todos os $A$. actinomycetemcomitans de indivíduos saudáveis foram classificados como minimamente leucotóxicos, confirmando trabalhos anteriores (CORTELLI et al., 2005).

Cortelli et al. (2005) relataram que pacientes brasileiros com periodontite agressiva apresentaram elevada prevalência de $A$. actinomycetemcomitans altamente leucotóxico, sendo também encontrado em proporções menores em pacientes com periodontite crônica, o que também foi constatado em nosso estudo. Sabe-se que, indivíduos inicialmente infectados por A. actinomycetemcomitans altamente leucotóxico tiveram maior progressão na perda de inserção clínica do que 
indivíduos que abrigaram isolados de mínima leucotoxicidade (CORTELLI et al., 2005; HAUBEK et al., 2004).

Indivíduos com periodontite agressiva, infectados pelo clone JP2, geralmente apresentam quadros clínicos mais graves e avançados do que indivíduos que não abrigam esse clone (HAUBEK et al., 2004). Bueno, Mayer e Di Rienzo (1998) demonstraram que indivíduos sadios abrigando $A$. actinomycetemcomitans com a deleção de 530-bp na região do promotor da leucotoxina foram mais susceptíveis à conversão de saúde para doença periodontal agressiva do que indivíduos que possuíam variantes de $A$. actinomycetemcomitans contendo a região do promotor sem a deleção. Portanto, a produção de leucotoxina contribui para patogenicidade de $A$. actinomycetemcomitans no desenvolvimento de periodontite, e variantes de máxima leucotoxicidade podem ser úteis para o diagnóstico e tratamento da periodontite agressiva, principalmente nos casos de jovens com descendência africana.

Estudos têm mostrado que biotipos e sorotipos específicos de $A$. actinomycetemcomitans podem apresentar enorme importância para o desenvolvimento da doença (DOGAN et al., 1999). Neste estudo, todos os 73 isolados foram agrupados em oito biotipos diferentes (I, II, III, V, VI,VIII, IX e X), sendo o biotipo II o mais predominante, o que confirma estudos anteriores (AVILACAMPOS; CARVALHO; ZELANTE, 1995). Dessa forma, o biotipo II e o biotipo $X$ colonizaram $12 \%$ e $8 \%$ dos pacientes com periodontite, respectivamente. Esses dois biotipos também foram observados nos pacientes sadios.

$O$ biotipo II parece ser o mais encontrado em pacientes brasileiros com periodontite (AVILA-CAMPOS; CARVALHO; ZELANTE, 1995; GAETTI-JARDIM et al., 2008), contudo poucos estudos têm mostrado a presença de diferentes biotipos de $A$. actinomycetemcomitans. $O$ processo de biotipagem de $A$. actinomycetemcomitans é extremamente útil para o desenvolvimento de estudos epidemiológicos, e principalmente nos que são realizados com indivíduos da mesma família, que podem abrigar bactérias do mesmo biotipo e sorotipo. Essas evidências sugerem que existe uma via de infecção entre familiares, a qual seria responsável pela natureza familiar da doença periodontal (GENCO; LOOS, 1991).

Dentre os diversos fatores de virulência que têm sido relatados para $A$. actinomycetemcomitans podem ser destacadas as fímbrias, sialidases, estruturas amorfas e a produção de adesinas e toxinas. Embora se saiba que esses 
microrganismos têm a capacidade de aderir às superfícies das células epiteliais bucais, o papel de alguns fatores envolvidos no processo de adesão ainda não é totalmente conhecido. Por outro lado, esses microrganismos também sintetizam uma quantidade significativa de polissacarídeos capsulares que são estruturalmente diferentes, indicando que, provavelmente, apresentem propriedades funcionais diferentes (DIAZ et al., 2006).

Em outros microrganismos orais, tais como Porphyromonas gingivalis, algumas vesículas de superfície têm sido observadas e associadas aos processos proteolíticos, à hemaglutinação e à coagregação bacteriana. Ainda, sugere-se que essas vesículas colaborem para a habilidade desses microrganismos disseminarem enterotoxinas e endotoxinas, que podem penetrar as barreiras das células epiteliais.

Segundo Nishihara et al. (1995), espécies encapsuladas são frequentemente encontradas na cavidade bucal e fazem parte da microbiota residente desse ecossistema. A cápsula foi observada em todos os isolados testados, no entanto não foi possível observar alguma correlação da presença desta estrutura com os processos de adesão e invasão. Este resultado sugere que, embora a cápsula seja necessária, não se constitui um fator primordial para este processo. Também, sabese que primeiramente, a cápsula tem a função de proteger $0 A$. actinomycetemcomitans da fagocitose e quando é produzido em grande quantidade colabora com a estabilização do processo adesivo às células epiteliais.

Vários estudos têm demonstrado a patogenicidade de bactérias orais encapsuladas, assim como a habilidade de induzir abscessos em animais experimentais. Entretanto, até o momento pouco se conhece sobre o papel que o polissacarídeo capsular de A. actinomycetemcomitans exerce sobre as células do hospedeiro (HENDERSON et al., 2003; SUZUKI et al., 2000).

$\mathrm{Na}$ Tabela 3, pode ser observado que a maioria dos A. actinomycetemcomitans avaliados neste estudo foram altamente adesivos, assim como aproximadamente $50 \%$ deles apresentaram capacidade invasiva. Este resultado reforça que os processos de adesão e invasão constituem-se eventos independentes e que, certamente, os fatores envolvidos em cada um desses processos são diferentes.

As células KB (carcinoma epidermóide oral) têm sido muito utilizadas por diversos pesquisadores nos ensaios de adesão e invasão de $A$. actinomycetemcomitans como modelo de células epiteliais gengivais (MEYER; SREENIVASAN; FIVES-TAYLOR, 1991). Em nosso estudo, estruturas semelhantes 
às fímbrias não foram observadas nos $A$. actinomycetemcomitans avaliados, no entanto esses isolados mostraram fenótipos adesivos, sugerindo-se que provavelmente mais de uma adesina e/ou proteína de membrana externa possam estar envolvidas no processo de adesão. Pruzzo, Dainelli e Ricchetti (1984) relataram a dificuldade de estudar as fímbrias devido à necessidade de condições adequadas de crescimento, assim como, a baixa concentração de ferro e diferentes temperaturas que afetam a expressão desta estrutura, sendo assim pouco conhecida.

Estudos têm mostrado que cepas de $A$. actinomycetemcomitans recém isoladas de material clínico são capazes de aderir a outros microrganismos e em substratos tais como vidro, plástico e hidroxiapatita (FINE et al., 1999a; KACHLANY; FINE; FIGURSKI, 2000). Esses autores também mostraram que o material amorfo extracelular produzido por $A$. actinomycetemcomitans colabora diretamente na conversão de cepas pouco aderentes em altamente aderentes (FINE et al., 1999b).

$\mathrm{Na}$ cavidade oral, um ambiente em constante mudança, as bactérias devem ser capazes de adaptar seus mecanismos de aderência a fim de persistir. Confinadas no interior de um biofilme, elas têm acesso aos nutrientes, são protegidas da ação de agentes antimicrobianos e se associam com células em vários estágios de crescimento, permitindo a rápida adaptação (COSTERTON; STEWART; GREENBERG, 1999).

Biofilmes de $A$. actinomycetemcomitans produzidos in vitro consistem de células fortemente empacotadas, imersas em uma matriz polimérica extracelular sintetizada pela própria bactéria. Essa matriz contém pili adesivo tipo IV, também conhecido como pili Flp-1, DNA extracelular e polissacarídeo, sendo que o maior deles é o poli-N-acetil-glicosamina, também conhecido como PGA (INOUE et al., 2003; KACHLANY et al., 2001; KAPLAN et al., 2004). Em nosso estudo, a maioria dos $A$. actinomycetemcomitans avaliados $(74,3 \%)$ isolados de pacientes com periodontite mostrou elevada capacidade de formar biofilmes nos substratos de vidro e de plástico, assim como dois dos três isolados do paciente sadio também mostraram essa capacidade.

A literatura tem relatado que isolados clínicos de $A$. actinomycetemcomitans formam biofilmes tenazes em superfícies abióticas e que cepas mutantes, que falham em formar biofilmes in vitro, são incapazes de colonizar a cavidade oral, de estimular resposta imune ou de causar perda óssea em animais experimentais com 
periodontite (FINE et al., 2001; SCHREINER et al., 2003). Além disso, biofilmes de A. actinomycetemcomitans produzidos in vitro exibiram resistência aumentada à morte por antissépticos bucais conhecidos, tais como Listerine, Meridol, Plax e clorohexidina, quando comparados com a resistência exibida por células de vida livre ou planctônicas (HAASE et al., 2006).

Dessa forma, sugere-se que o modo de crescimento em biofilme contribui para a habilidade de $A$ actinomycetemcomitans em colonizar a cavidade oral e causar doenças. Inoue et al. (2003) demonstraram que uma cepa de $A$. actinomycetemcomitans com mutação no gene f/p-1, que codifica a maior proteína fimbrial, foi capaz de formar biofilme mesmo sendo deficiente em fímbrias, sugerindo-se que essas estruturas não são essenciais para o crescimento adesivo em superfícies, mas são requeridos para melhorar as interações entre célula-célula e célula-superfície para estabilizar o biofilme.

Em nosso estudo, dos $70 \mathrm{~A}$. actinomycetemcomitans isolados de periodontite capazes de formar biofilmes, somente $38(54,3 \%)$ abrigaram o gene flp-1, reforçando a ideia de que possivelmente, além das fimbrias outras adesinas ou outros genes estão envolvidos no processo de formação de biofilme. Cabe lembrar que a aderência de $A$. actinomycetemcomitans é mediada pelo locus do gene tad (tight adherence), o qual inclui $f / p, r c p A$ e $r c p B$. Saito et al. (2010) demonstraram que a expressão dos genes $r c p A$ e $r c p B$ têm um papel decisivo na formação de biofilme por cepas de $A$. actinomycetemcomitans e para o estabelecimento de infecções persistentes em lesões periodontais.

Muitas bactérias que colonizam a cavidade oral expressam sialidases, degradando substratos de sialoglicoproteínas, e podem usar o acido siálico e açúcares primários como fontes de carbono, melhorando a sua sobrevivência, enquanto facilita seu acesso ao epitélio do hospedeiro. Estas enzimas podem ser produzidas por estreptococos, tais como Streptococcus oralis, $S$. intermedius e $S$. mitis que utilizam frequentemente o ácido siálico como fonte de carbono para auxiliar no crescimento (BYERS; HOMER; BEIGHTON, 1996).

Da mesma forma, a sialidase produzida por Porphyromonas gingivalis atua nos substratos de glicoproteína e parece participar na produção de cápsula, formação de biofilme, na resistência ao complemento e disseminação da infecção (LI et al., 2012). Similarmente, Tannerella forsythia exibe um crescimento dependente de sialidase em biofilmes orais (ROY et al., 2011). Honma, Mishima e Sharma (2011) 
demonstraram que essa enzima, produzida por T. forsythia, é importante em interações com células epiteliais gengivais humanas em um mecanismo que pode expor epítopos para colaborar na adesão e invasão.

Sabe-se que, muitas bactérias orais sialidase-positivas podem causar infecções extra orais, tais como endocardite, demonstrando a importância da degradação das barreiras naturais, como as mucosas do hospedeiro. Neste estudo, $82,2 \%$ dos $A$. actinomycetemcomitans avaliados foram produtores de sialidase. Trabalhos recentes têm mostrado que bactérias periodontais possuem vários sistemas de utilização e captação de ácido siálico, enquanto outras podem usar ácido siálico para evitar o reconhecimento pelo sistema imune do hospedeiro (STAFFORD et al., 2012).

A. actinomycetemcomitans HK 1651 possui o operon nan, contendo genes envolvidos no catabolismo de ácido siálico, enquanto que Fusobacterium nucleatum parece usar esta enzima (KAPATRAL et al., 2002). O verdadeiro envolvimento da enzima sialidase produzida por $A$. actinomycetemcomitans nos processos de adesão e invasão aos tecidos do hospedeiro, na formação de biofilmes ou mesmo em outros processos, ainda não está totalmente esclarecido.

Sabe-se que o processo de invasão é um pré-requisito para a patogenicidade de certas bactérias (WILSON; HENDERSON, 1995). A. actinomycetemcomitans além dos diversos fatores mencionados anteriormente, tais como fímbrias, hemaglutininas, cápsula, LPS e vesículas de membrana externa, produz diferentes enzimas capazes de perturbar os mecanismos de defesa do hospedeiro e iniciar a destruição tecidual. Assim, trabalhos têm mostrado que a invasão de $A$. actinomycetemcomitans em células humanas seria limitada à algumas cepas bacterianas, representando aproximadamente $25 \%$ das cepas invasivas presentes na microbiota da cavidade bucal (MEYER; SREENIVASAN; FIVES-TAYLOR, 1991).

Estudos sobre a invasão de $A$. actinomycetemcomitans estão em andamento, $\mathrm{e}$ a natureza fundamental do processo de internalização dessa bactéria tem se tornado mais claro. O processo - que envolve entrada, escape do vacúolo, multiplicação intracelular, e a propagação intracelular de célula-célula- compartilha similaridades com aqueles de Shigella flexneri e Listeria monocytogenes, importantes enteropatógenos. Enquanto microfilamentos da célula do hospedeiro estão envolvidos na entrada de $A$. actinomycetemcomitans, microtúbulos auxiliam na sua propagação (MEYER; MINTZ; FIVES-TAYLOR, 1997). Assim, o processo de invasão 
desse microrganismo é complexo e dinâmico.

A taxa de invasão de $A$. actinomycetemcomitans tem sido comparada à de outros patógenos periodontais como $P$. gingivalis, sendo que esta última bactéria apresenta um poder invasivo maior (NAKAGAWA et al., 2002). Meyer, Lippman e Fives-Taylor (1996) relataram que essas bactérias invasivas podem apresentar um comportamento pouco usual de transferência de uma célula para outra, dentro do mesmo hospedeiro e que este processo deveria ser mais profundamente estudado.

Dessa forma, bactérias que causam infecções crônicas, como a periodontite, e bactérias que causam doenças agudas, como a disenteria, têm desenvolvido estratégias de infecção similares (MEYER; MINTZ; FIVES-TAYLOR, 1997). Embora se tenha conhecimento sobre os mecanismos de invasão às células hospedeiras, os genes bacterianos requeridos para as diferentes etapas do processo de invasão ainda estão por ser identificados. Cabe lembrar que duas proteínas relacionadas à invasão, ApiA e ApiBC foram identificadas em A. actinomycetemcomitans, apresentando sequências similares às das adesinas e invasinas da família YadA de outras espécies bacterianas. Isto sugere uma possível conservação nos mecanismos utilizados para colonizar e invadir o epitélio, além disso, essas proteínas poderiam ser reconhecidas pelo sistema imune do hospedeiro por variação antigênica (LI et al., 2004).

O processo de invasão não é apenas influenciado por adesinas, responsáveis pela interação entre bactéria e hospedeiro. Trabalhos têm relatado que apaH pode ser necessário para a invasão por $A$. actinomycetemcomitans. Além disso, a expressão de outros produtos bacterianos como a de diadenosina tetrafosfatase, codificada por apaH, pode melhorar a sobrevivência bacteriana dentro do citoplasma das células eucarióticas (GAYWEE et al., 2002).

Homólogos do gene apaH de $A$. actinomycetemcomitans estão associados ao processo de invasão de outras bactérias patogênicas, tais como Escherichia coli e Salmonella enterica (BESSMAN et al., 2001; ISMAIL; HART; MC LENNAN, 2003). Saarela et al. (1999) demonstraram que a cepa de $A$. actinomycetemcomitans mutante, apaH deficiente, exibiu perda de invasibilidade às células $K B$, enquanto que a expressão de $\mathrm{ApaH}$ recombinante resultou em um fenótipo invasivo às células $\mathrm{KB}$ in vitro. A maioria dos $A$. actinomycetemcomitans avaliados neste estudo abrigaram o gene apaH; contudo alguns deles apresentaram este gene, mas não foram capazes de invadir as células KB, sugerindo que outros fatores possam estar 
envolvidos no processo de invasão desse microrganismo.

Em nosso estudo, 50\% dos $66 \mathrm{~A}$. actinomycetemcomitans com capacidade de adesão foram também capazes de invadir as células epiteliais KB, sugerindo-se que este microrganismo precise expressar o gene $f / p-1$ ou utilize algum outro mecanismo não avaliado neste estudo para realizar esse processo. Por outro lado, o envolvimento da proteína Flp-1 no processo de adesão às células epiteliais até hoje não é conhecido.

Estudos têm mostrado que o gene flp-1 está ligado ao genes tadABCDFG que, por sua vez, estão ligados ao operon tad em uma região com baixa concentração de $\mathrm{G}+\mathrm{C}$, ao lado dos genes $r c p A$ e $r c p B$, os quais são expressos especificamente por $A$. actinomycetemcomitans aderentes e que produzem colônias rugosas, não sendo observado em bactérias que produzem colônias lisas (FINE et al., 1999b).

$\mathrm{Na}$ Tabela 4, observa-se a presença de diferentes genes envolvidos na citotoxicidade dos $A$. actinomycetemcomitans isolados neste estudo. É importante salientar que todos os isolados testados apresentaram o promotor LTX, assim como, o gene Itx $A$ e que a maioria foi considerada altamente leucotóxica, o que representa um alerta principalmente para o especialista em Periodontia, com relação ao tratamento das doenças periodontais. O operon desta leucotoxina consiste de quatro

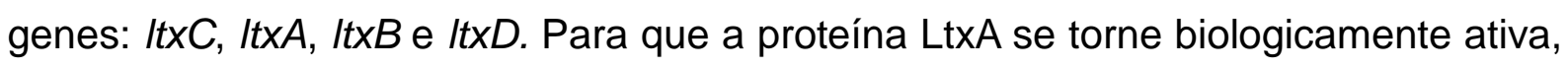
ela precisa ser acilada pela proteína LtxC e pelo carreador acil (LALLY et al., 1999). É importante lembrar que $A$. actinomycetemcomitans produz dois tipos de colônias, rugosas e lisas, e estudos têm mostrado que as colônias rugosas não apresentam a capacidade de produzir leucotoxina, diferentemente, das colônias lisas ou não aderentes que a secretam (KACHLANY; FINE; FIGURSKI, 2000).

A toxina distensora citoletal (Cdt) produzida por A. actinomycetemcomitans constitui-se em uma proteína ciclomoduladora com função imunossupressora. Esta toxina é o produto de um operon com três genes $(c d t A, c d t B, c d t C)$ que é encontrada em uma grande variedade de bactérias incluindo Escherichia coli, Shigella spp., Campylobacter spp., e Helicobacter spp. (SMITH; BAYLES, 2006). Acredita-se que o mecanismo de ação desta toxina ocorre por meio da atividade nuclease de CdtB (LARA-TEJERO; GÁLAN, 2000). O CDT de A. actinomycetemcomitans e de outras bactérias requer todas as três proteinas $C$ dt para causar a inibição do ciclo celular. Contudo, Shenker et al. (2001) têm relatado que CdtB recombinante ou purificado de A. actinomycetemcomitans é suficiente para bloquear células de linfócitos humanos. 
Dentre as principais espécies periodontopatogênicas, tais como Porphyromonas spp., Prevotella spp. e Fusobacterium spp., $A$. actinomycetemcomitans é a única que produz forte atividade CDT, apresentando genes cdt, uma vez que essa bactéria possui características peculiares que a diferenciam dos outros periodontopatógenos (YAMANO et al., 2003).

Em nosso estudo, os genes cdt foram detectados na maioria dos $A$. actinomycetemcomitans avaliados, sendo o gene cdtABC encontrado em $57,1 \%$ dos isolados de sítios com doença periodontal, concordando com outros trabalhos (FABRIS et al., 2002; YAMANO et al., 2003). Fabris et al. (2002) relataram que os genes cdt são comumente encontrados em $A$. actinomycetemcomitans de diferentes localizações geográficas e estão presentes em isolados de indivíduos brasileiros com periodontite crônica e agressiva, assim como de indivíduos sadios. Por outro lado, Tan, Song e Ong (2002) obtiveram resultados diferentes com indivíduos da China, demonstrando que 106 sítios com periodontite abrigaram $A$. actinomycetemcomitans e dentre eles, somente 13 sítios analisados apresentaram este microrganismo com genótipo cdt.

Kawamoto et al. (2009) demonstraram que cdtABC é frequentemente encontrado no genoma de $A$. actinomycetemcomitans, indicando que outros aspectos além da ausência desse gene poderiam influenciar a atividade tóxica dos isolados.

Vinte $A$. actinomycetemcomitans avaliados nesse estudo perderam pelo menos um dos genes $c d t$, confirmado pela análise por PCR. Quarenta desses 70 isolados exibiram amplicons quando o operon inteiro do gene $\operatorname{cdt} A B C$ foi amplificado, usando iniciadores homólogos aos genes $\operatorname{cdtA}$ e $\operatorname{cdtC}$. A atividade CDT foi observada com sobrenadante bacteriano de cinco isolados, nos quais $c d t A, \operatorname{cdt} C$ ou $\operatorname{cdt} A B C$ não foi detectado por PCR. Porém, o efeito tóxico desses isolados foi menor que 0 observado com o sobrenadante da cepa A. actinomycetemcomitans JP2. A ausência de amplicons nos isolados pode ser explicada pela deleção desses genes ou pela falta de homologia com os iniciadores, mas também, é possível observar a presença de deleção parcial sem perda de atividade tóxica. Além disso, tem sido demonstrado que cdtC é essencial para o efeito citotóxico de $A$. actinomycetemcomitans (SHENKER et al., 1999).

Portanto, no presente estudo foram descritas características fenotípicas e genotípicas de $A$. actinomycetemcomitans isolados de doença periodontal, assim 
como, adesão e citotoxicidade às células epiteliais in vitro e produção de enzima neuraminidase. Ainda, dois dos três isolados de indivíduo sadio apresentaram potenciais fatores de virulência que poderiam causar quadros de periodontite. 


\section{CONCLUSÕES}

Após a análise dos resultados obtidos nesse estudo, pode-se concluir que:

1. A presença de $A$. actinomycetemcomitans foi observada na maioria dos pacientes com periodontite crônica, embora tenha sido detectada em poucos pacientes com periodontite agressiva e em apenas um paciente saudável. O biotipo II foi o predominante nas bactérias isoladas;

2. A maioria dos A. actinomycetemcomitans de pacientes com periodontite e de pacientes sadios foram capazes de aderir, invadir e produzir citotoxicidade às células epiteliais orais;

3. Os genes apaH e flp-1 foram detectados na maioria $\operatorname{dos} A$. actinomycetemcomitans, tanto de pacientes com periodontite como de paciente sadio. A maioria dos isolados também abrigaram os genes $l x t$ e cdt, sendo considerados como altamente produtores de leucotoxina. 


\section{REFERÊNCIAS*}

ARMITAGE, G. Development of a classification system for periodontal diseases and conditions. Ann. Periodontol., v. 4, p. 1-6, 1999.

ASIKAINEN, S.; CHEN, C.; SAARELA, M.; SAXEN, U.; SLOTS, J. Clonal specificity of Actinobacillus actinomycetemcomitans in destructive periodontal disease. Clin. Infect. Dis., v. 25, p. 227-229, 1997.

AVILA-CAMPOS, M. J.; CARVALHO, M. A. R.; ZELANTE, F. Distribution of biotypes and antimicrobial susceptibility of Actinobacillus actinomycetemcomitans. Oral Microbiol. Immunol., v. 10, p. 382-384, 1995.

AVILA-CAMPOS, M. J.; SACCHI, C. T.; WHITNEY, A. M.; STEIGERWALT, A. G.; MAYER, L. W. Arbitrary primed-polymerase chain reaction for identification and epidemiologic subtyping of oral isolates of Fusobacterium nucleatum. $\mathbf{J}$. Periodontol., v. 70, p. 1202-1208, 1999.

BELIBASAKIS, G. N.; MATTSSON, A.; WANG, Y.; CHEN, C.; JOHANSSON, A. Cell cycle arrest of human gingival fibroblasts and periodontal ligament cells by Actinobacillus actinomycetemcomitans: involvement of the cytolethal distending toxin. APMIS, v. 112, p. 674-685, 2004.

BESSMAN, M. J.; WALSH, J. D.; DUNN, C. A.; SWAMINATHAN, J.; WELDON, J. E.; SHEN, J. The gene $y g d P$, associated with the invasiveness of Escherichia coli $\mathrm{K} 1$, designates a Nudix hydrolase, Orf176, active on adenosine (5')-pentaphospho-(5')adenosine (Ap5A). J. Biol. Chem., v. 12, p. 37834-37838, 2001.

BROGAN, J. M.; LALLY, E. T.; POULSEN, K.; KILIAN, M.; DEMUTH, D. R. Regulation of Actinobacillus actinomycetemcomitans expression: analysis of the promoter regions of leukotoxic and minimally leukotoxic strains. Infect. Immun., v. 62, p. 501-508, 1994.

BUENO, L.C.; MAYER, M. P. A.; DI RIENZO, J. M. Relationship between conversion of localized juvenile periodontitis-susceptible children from health to disease and Actinobacillus actinomycetemcomitans leukotoxin promoter structure. $\mathbf{J}$. Periodontol., v. 69, p. 998-1007, 1998.

BYERS, H. L.; HOMER, K. A.; BEIGHTON, D. Utilization of sialic acid by viridans streptococci. J. Dent. Res., v. 75, p. 1564-1571, 1996.

CORTELLI, S. C.; JORGE, A. O. C.; CORTELLI, J. R.; JORDAN, S. F.; HARASZTHY, V. I. Detection of highly and minimally leukotoxic Actinobacillus actinomycetemcomitans strains in patients with periodontal disease. Pesqui. Odontol. Bras., v. 17, n. 2, p. 183-188, 2003.

\footnotetext{
* De acordo com:

ASSOCIAÇÃO BRASILEIRA DE NORMAS TÉCNICAS. NBR 6023: informação e documentação: referências: elaboração. Rio de Janeiro, 2002.
} 
CORTELLI, J. R.; CORTELLI, S. C.; JORDAN, S.; HARASZTHY, V. I.; ZAMBON, J. $\mathrm{J}$. Prevalence of periodontal pathogens in Brazilians with aggressive or chronic periodontitis. J. Clin. Periodontol., v. 32, n. 8, p. 860-866, 2005.

COSTERTON, J. W.; STEWART, P. S.; GREENBERG, E. P. Bacterial biofilms: a common cause of persistent infections. Science, v. 284, p. 1318-1322, 1999.

CRAVIOTO, A.; GROSS, R. J.; SCOTLAND, S. M.; ROWE, B. An adhesive factor in strains of Escherichia coli belonging to the traditional infantile enterophatogenic serotype. Curr. Microbiol., v. 3, p. 95-99, 1979.

DIAZ, R.; AL GHOFAILY, L.; PATEL, J.; BALASHOVA, N. V.; FREITAS, A. C.; LABIB, I.; KACHLANY, S. C. Characterization of leukotoxin from a clinical strain of Actinobacillus actinomycetemcomitans. Microb. Pathogen., v. 40, p. 48-55, 2006.

DOGAN, N.; SAARELA, M.; JOUSIMIES-SOMER, H.; ALALUUSUA, S.; ASIKAINEN, S. Actinobacillus actinomycetemcomitans serotype e-biotypes, genetic diversity and distribution in relation to periodontal status. Oral Microbiol. Immunol., v. 14, p. 98103, 1999.

FABRIS, A. S.; DI RIENZO, J. M.; WIKSTROM, M.; MAYER, M. P. A. Detection of cytolethal distending toxin activity and cdt genes in Actinobacillus actinomycetemcomitans isolates from geographically diverse populations. Oral Microbiol. Immunol., v. 17, p. 231-238, 2002.

FINE, D. H.; FURGANG, D.; KAPLAN, J.; CHARLESWORTH, J.; FIGURSKI, D. H. Tenacious adhesion of Actinobacillus actinomycetemcomitans strain Cl1000 to salivary coated hydroxyapatite. Arch. Oral Biol., v. 44, p. 1063-1076, 1999a.

FINE, D. H.; FURGANG, D.; KAPLAN, J.; SCHREINER, H. C.; GONCHAROFF, P.; CHARLESWORTH, J.; GHAZWAN, G.; FITZGERALD-BOCARSLY, P.; FIGURSKI, D. $\mathrm{H}$. Phenotypic variation in Actinobacillus actinomycetemcomitans during laboratory growth implications for virulence. Microbiology, v. 145, p. 1335-1337, 1999b.

FINE, D. H.; GONCHAROFF, P.; SCHREINER, H.; CHANG, K. M.; FURGANG, D.; FIGURSKI, D. Colonization and persistence of rough and smooth colony variants of Actinobacillus actinomycetemcomitans in the mouths of rats. Arch. Oral. Biol., v. 46, p. 1065-1078, 2001.

FINE, D. H. et al. The Actinobacillus actinomycetemcomitans autotransporter adhesin Aae exhibits specificity for buccal epithelial cells from humans and old world primates. Infect. Immun., v. 73, n. 4, p. 1947-1953, 2005.

FIVES-TAYLOR, P. M.; MEYER, D. H.; MINTZ, K. P.; BRISSETTE, C. Virulence factors of Actinobacillus actinomycetemcomitans. Periodontol. 2000, v. 20, p. 136167, 1999.

GAETTI-JARDIM, E.; WAHASUGUI, T. C.; TOMAZINHO, P. H.; MARQUES, M. M.; NAKANO, V.; AVILA-CAMPOS, M. J. Distribution of biotypes and leukotoxic activity of Aggregatibacter actinomycetemcomitans isolated from Brazilian patients with 
chronic periodontitis. Braz. J. Microbiol., v. 39, p. 658-663, 2008.

GAJARDO, M.; SILVA, N.; GOMEZ, L.; LEON, R.; PARRA, B.; CONTRERAS, A.; GAMONAL, J. Prevalence of periodontopathic bacteria in aggressive periodontitis patients in a Chilean population. J. Periodontol., v. 76, p. 289-294, 2005.

GAYWEE, J.; XU, W.; RADULOVIC, S.; BESSMAN, M. J.; AZAD, A. F. The Rickettsia prowazekii invasion gene homolog (inv $A$ ) encodes a nudix hydrolase active on adenosine (5')-pentaphospho-(5')-adenosine. Mol. Cell. Proteomics, v. 1, p. 179183, 2002.

GENCO, R. J.; LOOS, B. G. The use of genomic DNA fingerprinting in studies of the epidemiology of bacteria in periodontitis. J. Clin. Microbiol., v. 18, p. 396-425, 1991.

GENCO, R. J. Host responses in periodontal diseases: current concepts. J. Periodontol., v. 63, n. 4, p. 338-355, 1992.

HAASE, E. M.; BONSTEIN, T.; PALMER, R. J.; SCANNAPIECO, F. A. Enviromental influences on Actinobacillus actinomycetemcomitans biofilm formation. Arch. Oral. Biol., v. 51, p. 299-314, 2006.

HAUBEK, D.; DI RIENZO, J. M.; TINOCO, E. M.; WESTERGAARD, J.; LOPEZ, N. J.; CHUNG, C. P.; POULSEN, K.; KILIAN, M. Racial tropism of a highly toxic clone of Actinobacillus actinomycetemcomitans associated with juvenile periodontitis. J. Clin. Microbiol., v. 35, p. 3037-3042, 1997.

HAUBEK, D.; ENNIBI, O. K.; POULSEN, K.; BENZARTI, N.; BAELUM, V. The highly leukotoxic JP2 clone of Actinobacillus actinomycetemcomitans and progression of periodontal attachment loss. J. Dent. Research, v. 83, p. 767-770, 2004.

HENDERSON, B.; NAIR, S. P.; WARD, J. M.; WILSON, M. Molecular pathogenicity of the oral opportunistic pathogen Actinobacillus actinomycetemcomitans. Annu. Rev. Microbiol., v. 57, p. 29-55, 2003.

HONMA, K.; MISHIMA, E.; SHARMA, A. Role of Tannerella forsythia NanH sialidase in epithelial cell attachment. Infect. Immun., v. 79, p. 393-401, 2011.

INOUE, T. et al. Biofilm formation by a fimbriae-deficient mutant of Actinobacillus actinomycetemcomitans. Microbiol. Immunol., v. 47, p. 877-881, 2003.

ISMAIL, T. M.; HART, C. A.; MC LENNAN, A. G. Regulation of dinucleoside poliphosphate pools by the $y g d P$ and $a p a H$ hydrolases is essencial for the ability of Salmonella enterica serovar typhimurium to invade cultured mammalian cells. J. Biol. Chem., v. 278, p. 32602-32607, 2003.

JARDIM-JUNIOR, E. G.; BOSCO, J. M.; LOPES, A. M.; LANDUCCI, L. F.; JARDIM, E. C.; CARNEIRO, S. R. Occurrence of Actinobacillus actinomycetemcomitans in patients with chronic periodontitis, aggressive periodontitis, healthy subjects and children with gingivitis in two cities of the state of São Paulo, Brazil. J. Appl. Oral Sci., v. 14, n. 3, p. 153-156, 2006. 
JOHNSON, W. M.; LIOR, H. Response of Chinese hamster ovary cells to a cytolethal distending toxin (CDT) of Escherichia coli and possible mis-interpretation as a heat labile (LT) enterotoxin. FEMS Microbiol. Lett., v. 43, p. 19-23, 1987.

KACHLANY, S. C.; FINE, D. H.; FIGURSKI, D. H. Secretion of RTX leukotoxin by Actinobacillus actinomycetemcomitans. Infect. Immun., v. 68, p. 6094-6100, 2000.

KACHLANY, S. C.; PLANET, P. J.; DE SALLE, R.; FINE, D. H.; FIGURSKI, D. H.; KAPLAN, J. B. flp-1, the first representative of a new pilin gene subfamily, is required for non-specific adherence of Actinobacillus actinomycetemcomitans. Mol. Microbiol., v. 40, p. 542-554, 2001.

KAPATRAL, V. et al. Genome sequence and analysis of the oral bacterium Fusobacterium nucleatum strain ATCC 25586. J. Bacteriol., v. 184, p. 2005-2018, 2002.

KAPLAN, J. B.; MEYENHORFER, M. F.; FINE, D. H. Biofilm growth and detachment of Actinobacillus actinomycetemcomitans. J. Bacteriol., v. 185, p. 1399-1404, 2003.

KAPLAN, J. B. et al. Genes involved in the synthesis and degradation of matrix polysaccharide in Actinobacillus actinomycetemcomitans and Actinobacillus pleuropneumoniae biofilms. J. Bacteriol., v. 186, p. 8213-8220, 2004.

KAWAMOTO, D.; ANDO, E. S.; LONGO, P. L.; NUNES, A. C. R.; WIKSTROM, M.; MAYER, M. P. A. Genetic diversity and toxic activity of Aggregatibacter actinomycetemcomitans isolates. Oral Microbiol. Immunol., v. 24, p. 493-501, 2009.

KOROSTOFF, J.; WANG, J. F.; KIEBA, I.; MILLER, M.; SHENKER, B. J.; LALLY, E. T. Actinobacillus actinomycetemcomitans leukotoxin induces apoptosis in HL-60 cells. Infect. Immun., v. 66, p. 4474-4483, 1998.

LALLY, E. T.; HILL, R. B.; KIRBA I. R.; KOROSOFF, J. The interaction between RTX toxins and target cells. Trends Microbiol., v. 7, p. 356-361, 1999.

LARA-TEJERO, M.; GALÁN, J. E. A bacterial toxin that controls cell cycle progression as a deoxyribonuclease I-like protein. Science, v. 290, p. 354-357, 2000.

LI, C. et al. Abrogation of neuraminidase reduces biofilm formation, capsule biosynthesis, and virulence of Porphyromonas gingivalis. Infect. Immun., v. 80, p. 313, 2012.

LI, L.; MATEVSKI, M.; ASPIRAS, M.; ELLEN, R. P.; LÉPINE, G. Two epithelial cell invasion-related loci of the oral pathogen Actinobacillus actinomycetemcomitans. Oral Microbiol. Immunol., v. 19, p. 16-25, 2004.

LINDHE, J.; RANNEY, R.; LAMSTER, I. et al. Consensus report: Chronic periodontitis. Ann. Periodontol., v. 4, p. 38, 1999. 
MALHEIROS, V. J.; AVILA-CAMPOS, M. J. Detection of pathogens from periodontal lesions. Rev. Saúde Públ., v. 38, p. 723-728, 2004.

MENG, S.; ZHAO, L.; YANG, H.; WU, Y.; OUYANG, Y. Prevalence of Actinobacillus actinomycetemcomitans in Chinese chronic periodontitis patients and periodontally healthy adults. Quintessence Int., v. 40, n. 1, p. 53-60, 2009.

MEYER, D. H.; SREENIVASAN, P. K.; FIVES-TAYLOR, P. M. Evidence for invasion of a human oral cell line by Actinobacillus actinomycetemcomitans. Infect. Immun., v. 59, p. 2719-2726, 1991.

MEYER, D. H.; FIVES-TAYLOR, P. M. Characteristics of adherence of Actinobacillus actinomycetemcomitans to epithelial cells. Infect. Immunol., v. 62, p. 928-935, 1994.

MEYER, D. H.; LIPPMAN, J. E.; FIVES-TAYLOR, P. M. Invasion of epithelial cells by Actinobacillus actinomycetemcomitans: a dynamic multistep process. Infect. Immun., v. 64, p. 2988-2997, 1996.

MEYER, D. H.; MINTZ, K. P.; FIVES-TAYLOR, P. M. Models of invasion of enteric and periodontal pathogens into epithelial cells: a comparative analysis. Crit. Rev. Oral Biol. Med., v. 8, n. 4, p. 389-409, 1997.

MÖLLER, A. J. R. Microbiological examination of root canals and periapical tissue of human teeth. Odontol. Tidskr., v. 74, p. 1-380, 1966.

MOMBELLI, A.; CASAGNI, F.; MADIANOS, P. N. Can presence or absence of periodontal pathogens distinguish between subjects with chronic and aggressive periodontitis? A systematic review. J. Clin. Periodontol., v. 29, n. 3, p. 10-21, 2002.

MUHLE, I.; RAU, J.; RUSKIN, J. Vertebral osteomyelitis due to Actinobacillus actinomycetemcomitans. J. Am. Med. Assoc., v. 241, p. 1824-1825, 1979.

NAKAGAWA, I.; AMANO, A.; KOBINIWA, M.; NAKAMURA, T.; KAWABATA, S.; HAMADA, S. Functional differences among FimA variants of Porphyromonas gingivalis and their effects on adhesion to and invasion of human epithelial cells. Infect. Immun., v. 70, p. 277-285, 2002.

NAKANO, V.; AVILA-CAMPOS, M. J. Virulence markers and antimicrobial susceptibility of bacteria of Bacteroides fragilis group isolated from stool of children with diarrhea in São Paulo, Brazil. Mem. Inst. Oswaldo Cruz, v. 99, p. 307-312, 2004.

NAKANO, V.; PIAZZA, R. M. F.; AVILA-CAMPOS, M. J. A rapid assay of the sialidase activity species of the Bacteroides fragilis group by using peanut lectin hemaggluination. Anaerobe, v. 12, p. 238-341, 2006.

NAKANO, V.; PIAZZA, R. M. F.; CIANCIARULLO, A. M.; BUERIS, V.; SANTOS, M. F.; MENEZES, M. A.; MENDES-LEDESMA, M. R. B.; SZULCZEWSKI, V.; ELIAS, W. P.; PUMBWE, L.; WEXLER, H.; AVILA-CAMPOS, M. J. Adherence and invasion of Bacteroidales isolates from the human intestinal tract. Clin. Microbiol. Infect., v. 14, 
p. 955-963, 2008.

NISHIHARA, T.; UEDA, N.; AMANO, K.; ISHIHARA, Y.; HAYAKAWA, H.; KUROYANAGI, T.; OHSAKI, Y.; NAGATA, K.; NOGUCHI, T. Actinobacillus actinomycetemcomitans Y4 capsular-polysaccharide-like polysaccharide promotes osteoclast-like cell formation by interleukin-1 alpha production in mouse marrow cultures. Infect. Immun., v. 63, p. 1893-1898, 1995.

PAGE, M. I.; KING, E. O. Infection due to Actinobacillus actinomycetemcomitans and Haemophilus aphrophilus. N. Engl. J. Med., v. 275, p. 181-188, 1966.

PICKETT, C. L.; WHITEHOUSE, C. A. The cytolethal distending toxin family. Trends Microbiol., v. 7, p. 292-297, 1999.

PRUZZO, C.; DAINELLI, B.; RICCHETTI, M. Piliated Bacteroides fragilis strains adhere to epithelial cells and are more sensitive to phagocytosis by human neutrophils than nonpiliated strains. Infect. Immun., v. 43, p. 189-194, 1984.

ROSE, J. E.; MEYER, D. H.; FIVES-TAYLOR, P. M. Aae, an autotransporter involved in adhesion of Actinobacillus actinomycetemcomitans to epithelial cells. Infect. Immunol., v. 71, p. 2384-2393, 2003.

ROY, S.; HONMA, K.; DOUGLAS, I.; SHARMA, A; STAFFORD, G. P. Role of sialidase in glycoprotein utilization by Tannerella forsythia. Microbiology, v. 157, p. 3195-3202, 2011.

SAARELA, M.; LIPPMANN, J. E.; MEYER, D. H.; FIVES-TAYLOR, P. M. The Actinobacillus actinomycetemcomitans apaH gene is implicated in invasion of epithelial cells. J. Dent. Res., v. 78, p. 1225, 1999.

SAITO, T.; ISHIHARA, K.; RYU, M.; OKUDA, K.; SAKURAI, K. Fimbriae-associated genes are biofilm-forming factors in Aggregatibacter actinomycetemcomitans strains. Bull. Tokyo Dent. Coll., v. 51, n. 3, p. 145-150, 2010.

SCHAUER, R. Sialic acids and their role as biological masks. Trends Biochem. Sci., v. 10, p. 357-360, 1985.

SCHREINER, H. C. et al. Tight-adherence genes of Actinobacillus actinomycetemcomitans are required for virulence in a rat model. Proc. Natl. Acad. Sci. USA, v. 100, p. 7295-7300, 2003.

SHENKER, B. J.; MC KAY, T.; DATAR, S.; MILLER, M.; CHOWHAN, R.; DEMUTH, D. Actinobacillus actinomycetemcomitans immunosuppressive protein is a member of the family of cytolethal distending toxins capable of causing a G2 arrest in human T cells. J. Immunol., v. 162, p. 4773-4780, 1999.

SHENKER, B. J.; HOFFMASTER, R. H.; ZEKAVAT, A.; LALLY, N. E. T.; DEMUTH, D.; YAMAGUCHI, $\mathrm{N}$. Induction of apoptosis in human $\mathrm{T}$ cells by Actinobacillus actinomycetemcomitans cytolethal distending toxin is a consequence of $\mathrm{G}_{2}$ arrest of 
the cell cycle. J. Immunol., v. 167, p. 435- 441, 2001.

SLOTS, J.; REYNOLDS, H. S.; GENCO, R. J. Actinobacillus actinomycetemcomitans in human periodontal disease: a cross-sectional microbiological investigation. Infect. Immun., v. 29, n. 3, p. 1013-1020, 1980.

SLOTS, J. Selective medium for Actinobacillus actinomycetemcomitans. J. Clin. Microbiol., v. 15, p. 606-609, 1982.

SLOTS, J.; BRAGD, L.; WIKSTROM, M.; DAHLEN, G. The occurrence of Actinobacillus actinomycetemcomitans, Bacteroides gingivalis and Bacteroides intermedius in destructive periodontal disease in adults. J. Clin. Periodontol., v. 13, p. 570-577, 1986.

SMITH, J. L.; BAYLES, D. O. The contribution of cytolethal distending toxin to bacterial pathogenesis. Crit. Rev. Microbiol., v. 32, p. 227-248, 2006.

STAFFORD, G.; ROY, S.; HONMA, K.; SHARMA, A. Sialic acid, periodontal pathogens and Tannerella forsythia: stick around and enjoy the feast! Mol. Oral Microbiol., v. 27, p. 11-22, 2012.

SUZUKI, N.; NAKANO, Y.; YOSHIDA, Y.; NAKAO, H.; YAMASHITA, Y.; KOGA, T. Genetic analysis of the gene cluster for the synthesis of serotype a-specific polysaccharide antigen in Actinobacillus actinomycetemcomitans. Biochem. Biophys. Acta, v. 1517, p. 135-138, 2000.

TAKAMATSU, N.; YANO, K.; HE, T.; UMEDA, M.; ISHIKAWA, I. Effect of initial periodontal therapy on the frequency of detecting Bacteroides forsythus, Porphyromonas gingivalis e Actinobacillus actinomycetemcomitans. J. Periodontol., v. 70 , p. $574-580,1999$.

TAN, K. S.; SONG K. P.; ONG, G. Cytolethal distending toxin of Actinobacillus actinomycetemcomitans. Occurrence and association with periodontal disease. J. Periodontal Res., v. 37, p. 268-272, 2002.

TANG, P.; FOUBISTER, V.; PUCCIARELLI, M. G.; FINLAY, B. B. Methods to study bacterial invasion. J. Microbiol. Methods, v. 18, p. 227-240, 1993.

TSAI, C. C.; MCARTHUR, W. P.; BAEHNI, P. C.; HAMMOND, B. F.; TAICHMAN, N. $S$. Extraction and partial characterization of a leukotoxin from a plaque-derived gramnegative microorganism. Infect. Immun., v. 25, p. 427-439, 1979.

WILSON, M.; HENDERSON, B. Virulence factors of Actinobacillus actinomycetemcomitans relevant to the pathogenesis of inflammatory periodontal diseases. FEMS Microbiol. Rev., v. 17, p. 365-379, 1995.

YAMANO, R. et al. Prevalence of cytolethal distending toxin production in periodontopathogenic bacteria. J. Clin. Microbiol., v. 41, p. 1391-1398, 2003.

YANO-HIGUCHI, K.; TAKAMATSU, N.; HE, T.; UMEDA, M.; ISHIKAWA, I. Prevalence of Bacteroides forsythus, Porphyromonas gingivalis and Actinobacillus 
actinomycetemcomitans in subgingival microflora of Japanese patients with adult and rapidly progressive periodontitis. J. Clin. Periodontol., v. 27, n. 8, p. 597-602, 2000.

ZADEH, H. H.; NICHOLS, F. C.; MIYASAKI, K. T. The role of the cell-mediated immune response to Actinobacillus actinomycetemcomitans and Porphyromonas gingivalis in periodontitis. Periodontol. 2000, v. 20, p. 239-288, 1999.

ZAMBON, J. J.; HARASZTHY, V. I.; HARIHARAN, G.; LALLY, E. T.; DEMUTH, D. R. The microbiology of early-onset periodontitis: association of highly toxic Actinobacillus actinomycetemcomitans strains with localized juvenile periodontitis. J. Periodontol., v. 67, p. 282-290, 1996. 


\section{APÊNDICE - Artigo de Periódico}

WAHASUGUI, T. C.; NAKANO, V.; PIAZZA, R. M. F.; AVILA-CAMPOS, M. J. Phenotypic and genotypic features of Aggregatibacter actinomycetemcomitans isolated from patients with periodontal disease. Diagn. Microbiol. Infect. Dis., v. 75, p. 366-372, 2013. 
Provided for non-commercial research and education use. Not for reproduction, distribution or commercial use.

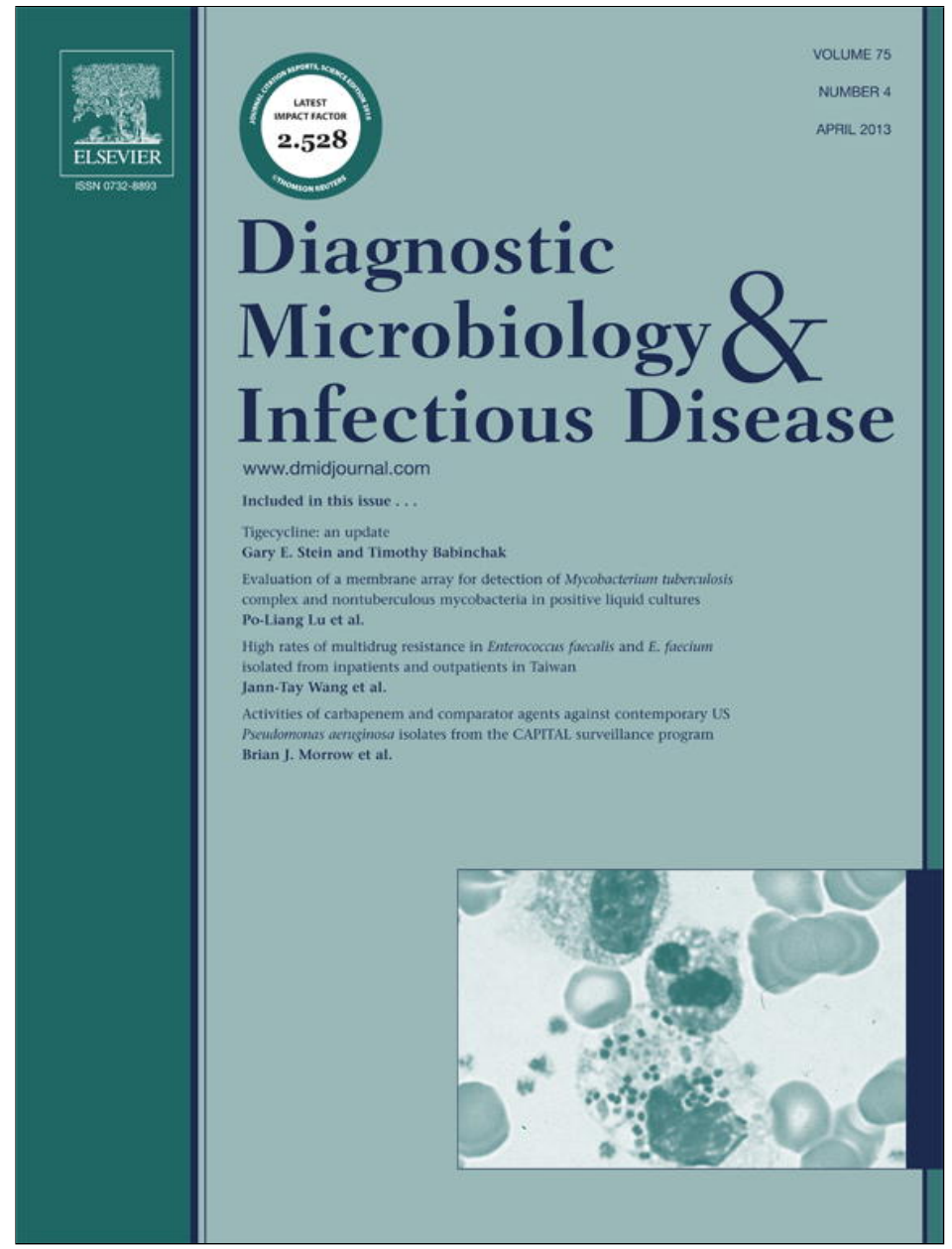

This article appeared in a journal published by Elsevier. The attached copy is furnished to the author for internal non-commercial research and education use, including for instruction at the authors institution and sharing with colleagues.

Other uses, including reproduction and distribution, or selling or licensing copies, or posting to personal, institutional or third party websites are prohibited.

In most cases authors are permitted to post their version of the article (e.g. in Word or Tex form) to their personal website or institutional repository. Authors requiring further information regarding Elsevier's archiving and manuscript policies are encouraged to visit:

http://www.elsevier.com/copyright 


\title{
Phenotypic and genotypic features of Aggregatibacter actinomycetemcomitans isolated from patients with periodontal disease
}

\author{
Thais C. Wahasugui a, ${ }^{\text {, }}$, Viviane Nakano ${ }^{\mathrm{a}, 1}$, Roxane M.F. Piazza ${ }^{\mathrm{b}}$, Mario J. Avila-Campos ${ }^{\mathrm{a}, *}$ \\ a Laboratório de Anaeróbios, Departamento de Microbiologia, Instituto de Ciências Biomédicas, Universidade de São Paulo, São Paulo, SP \\ b Laboratório de Bacteriologia, Instituto Butantan, São Paulo, SP, Brazil
}

\section{A R T I C L E I N F O}

\section{Article history:}

Received 19 October 2012

Received in revised form 17 December 2012

Accepted 19 December 2012

Available online 5 February 2013

Keywords:

Adherence

Invasion

Periodontal disease

Aggregatibacter actinomycetemcomitans

\begin{abstract}
A B S T R A C T
Aggregatibacter actinomycetemcomitans is strongly implicated in the pathogenesis of periodontitis. In this study, the phenotypic and genotypic features of A. actinomycetemcomitans and the presence of genes involved in toxicity were determined. Sixty-five patients with periodontal pocket and 48 healthy subjects were evaluated. Biotyping, adherence and invasion, neuraminidase and biofilm production, presence of capsule and fimbria, as well as the presence of $f l p-1, a p a H, l t x$, and $c d t$ genes were determined. Biotype II was the most prevalent. Sixty-six strains were adherent and 33 of them were able to invade KB cells. Sixty strains produced neuraminidase, and 55 strains biofilms. Strains showed capsule but not fimbriae. Forty-six strains were cytotoxic, and most strains harbored the $a p a H$ and $\mathrm{flp}-1$ genes. LTX promoter and the ltxA gene were observed in all strains from periodontal patients. The $c d t A$ gene was observed in 50 (71.4\%) strains, $c d t B$ in 48 (68.6\%) strains, $c d t C$ in 60 (85.7\%), and $c d t A B C$ in $40(57.1 \%)$ strains. The presence of $A$. actinomycetemcomitans harboring the $c d t C$ gene from healthy subjects may represent a transitory microorganism in the oral microbiota. More studies are necessary to understand the real role of this microorganism in the pathogenesis of periodontal disease.
\end{abstract}

(c) 2013 Elsevier Inc. All rights reserved.

\section{Introduction}

Bacterial adherence is the first step in invading cells. Adherence of pathogens on eukaryote cells is mediated by adhesins, lipopolysaccharide, or fimbriae, which may be regulated either by the host's immune system or by environmental factors (Xie et al., 1997). Aggregatibacter actinomycetemcomitans is a capnophylic Gramnegative coccobacillus, is nonmotile, is non-spore forming, and has been strongly implicated in the pathogenesis of periodontitis, mainly in aggressive periodontitis, and in systemic infections such as endocarditis and soft tissue abscesses (Nakano et al., 2007). Aggressive periodontitis often occurs in young people and causes a rapid loss of attachment and alveolar bone affecting teeth, particularly first molars and incisors (Slots and Ting, 1999).

An important virulence factor produced by A. actinomycetemcomitans is the leukotoxin that is genetically composed of a cluster of 4 genes that gives to this species the ability to kill human polymorphonuclear leukocytes (Lally et al., 1999). Leukotoxic A. actinomycetemcomitans

\footnotetext{
This study was supported by Grant CAPES (2472/09).

* Corresponding author. Tel.: +55-11-3091-7344/7354; fax: +55-11-3091-7344/ 7354.

E-mail address: mariojac@usp.br (M.J. Avila-Campos).

These authors contributed equally to this work.
}

strains are grouped by the variation in the transcriptional regulation of the leukotoxin genes into highly and minimally leukotoxic strains. Highly leukotoxic strains show a deletion (530 bp) in the promoter region of the operon that enhances transcription (Brogan et al., 1994). The cytolethal distending toxin (CDT) is another implicated virulence factor in the pathogenesis of periodontal disease. The prevalence of CDTexpressing clones can vary among populations of the same bacterial species (Tan et al., 2002; Whitehouse et al., 1998).

This microorganism produces adhesins used in early events of infectious processes by attaching to specific receptors on oral mucosa and dental plaque. The bacterial ability of adherence to oral surfaces is an important property of biofilm production which is a pili- or fimbriae-mediated process (Kachlany et al., 2001).

Fives-Taylor et al. (1996) showed that the adhesive property of A. actinomycetemcomitans could be associated with the outer membrane, extracellular amorphous material, or extracellular vesicles. In addition, this microorganism produces fimbriae that are composed of repeating subunits of the 6.5-kDa Flp1 protein (fimbrial low-molecular-weight protein). This Flp1 protein represents a novel type IV pilin that is homologous to type IVB found in Vibrio cholerae and Escherichia coli. In addition, this protein is encoded by flp-1 and flp-2 genes (Kaplan et al., 2003), and is the major structural component of fibrils (Kachlany et al., 2001). A. actinomycetemcomitans produces rough and smooth colonies which are characterized for producing fimbriae, and smooth colonies produce extracellular 
microvesicles that are associated with the attachment process (Meyer et al., 1996; Saito et al., 2010).

Bacterial sialidases are considered virulence factors in several pathogenic organisms which colonize mucosal surfaces, since this enzyme catalyzes the sialic acid ( $\mathrm{N}$-acetyl neuraminic acid) hydrolysis from glycoproteins, glycolipids, and polysaccharides of the cell membrane, exposing the $\beta$-galactosyl determinant which acts in the adherence process among bacteria and host's mucosa. Several bacterial strains show a neuraminidase activity, and it has been suggested that this activity plays a role in the bacterial attachment to animal cells, as well as in the hemagglutination process (Moncla et al., 1990; Nakano et al., 2006).

A. actinomycetemcomitans is a biofilm-forming bacterium on dental surfaces and epithelial cells using its own extracellular polymer. This biofilm contains bacterial cells producing adhesive type IV pili. In addition, this microorganism also produces a polysaccharide, poly- $\beta-1,6-N$-acetyl-D-glucosamine, which is also associated with adherence and invasion. In this study, the phenotypic and genotypic features of $A$. actinomycetemcomitans and the presence of genes involved in toxicity were determined.

\section{Materials and methods}

\subsection{Patients and sample collection}

Thirty-five male and 30 female patients between 20 and 50 years old, with clinical and radiographic evidence of alveolar bone loss confined to the molar and incisor teeth, and periodontal pocket depth equal to or exceeding $5 \mathrm{~mm}$, were evaluated. Forty-eight healthy subjects ( 30 men and 18 women between 20 and 45 years old) were also included, and none of them showed any gingival inflammation or bleeding on probing. None of them had used antibiotics 3 months prior to the sample collection. This study was approved by the Ethic Commission of the Institute of Biomedical Sciences, USP (Process No. $662 / C E P)$. Supragingival biofilm was removed from the mesial surface of 2 affected teeth by using sterile cotton pledgets. Subgingival samples were obtained by 2 fine sterile paper points (Dentsply, RJ, Brazil), inserted to the depth of the gingival site and left in place for $60 \mathrm{~s}$, and then placed into $2 \mathrm{~mL}$ of viability maintaining microbiostatic medium (VMGA III) transport medium and processed within $2 \mathrm{~h}$ of collection.

\subsection{Bacterial isolation and identification}

Clinical samples were 10 -fold diluted and plated onto a trypticase soy-serum bacitracin-vancomycin (TSBV) agar (Slots, 1982). After 72 h of incubation at $37^{\circ} \mathrm{C}$ in $90 \% \mathrm{~N}_{2}+10 \% \mathrm{CO}_{2}, 1$ to 2 suspected colonies from each subgingival sample were cultured on Brucella blood agar supplemented with $0.5 \%$ yeast extract, $5 \mathrm{mg} / \mathrm{mL}$ haemin, and $1 \mathrm{mg} / \mathrm{mL}$ menadione, and then identified by Gram staining, catalase production, susceptibility to $\mathrm{NaF}$, and biochemical tests by fermenting glucose, fructose, and mannose but not lactose, starch, sucrose, or trehalose (Slots et al., 1980). All the A. actinomycetemcomitans strains were stored at $-80{ }^{\circ} \mathrm{C}$ in $20 \%$ skimmed milk.

\subsection{Biotyping}

All isolates were biotyped on the basis of the variable fermentation of dextrin, maltose, mannitol, and xylose (Slots et al., 1980).

\subsection{Adherence assay}

Adherence assays using $1.0 \times 10^{5} \mathrm{~KB}$ cells (human oral epidermoid carcinoma cells) were performed as previously described (Cravioto et al., 1979; Nakano et al., 2008). Briefly, $960 \mu \mathrm{L}$ of RPMI 1640 medium (Cultilab, SP, Brazil) with fetal bovine serum ( $2 \% \mathrm{v} / \mathrm{v})$ were inoculated with $40 \mu \mathrm{L}$ of bacterial culture (ca. $1.5 \times 10^{8}$ cells $/ \mathrm{mL}$ ). Plates were incubated ( $5 \mathrm{~h}$ in $5 \% \mathrm{CO}_{2}$ ), washed 3 times with $0.1 \mathrm{~mol} / \mathrm{L}$ phosphatebuffered saline (PBS) (136 mmol/L NaCl, $2.7 \mathrm{mmol} / \mathrm{L} \mathrm{KCl}, 8.1 \mathrm{mmol} / \mathrm{L}$ $\mathrm{Na}_{2} \mathrm{HPO}_{4}, 1.5 \mathrm{mmol} / \mathrm{L} \mathrm{KH}_{2} \mathrm{PO}_{4}, \mathrm{pH} 7.4$ ), fixed (absolute methanol), and stained with May-Grünwald-Giemsa stain. The enteropathogenic Escherichia coli 0127:H6 (E2348/69) strain displaying a localized adhesion pattern was used as control. All assays were performed in duplicate.

\subsection{Invasion assay}

Invasion assays were performed as described by Nakagawa et al. (2002), with modifications. Aliquot of $100 \mu \mathrm{L}$ of a 24 -h culture with ca. $1.5 \times 10^{8}$ cells $/ \mathrm{mL}$ was added to ca. $1.0 \times 10^{5} \mathrm{~KB}$ cells and then incubated $\left(2 \mathrm{~h}\right.$ in $5 \% \mathrm{CO}_{2}$ ). Nonadherent bacteria were killed by incubation ( $1 \mathrm{~h}$ in $5 \% \mathrm{CO}_{2}$, at $37{ }^{\circ} \mathrm{C}$ ) in $1 \mathrm{~mL}$ of Dulbecco's Modified Eagle's Medium containing 2\% fetal bovine serum with $300 \mu \mathrm{g} / \mathrm{mL}$ of gentamycin. Then, cells were washed 3 times in PBS and lysed with $400 \mu \mathrm{L}$ of Triton-X-100 (1\%, v/v). After mixing, $100 \mu \mathrm{L}$ was plated on Brucella blood agar (Difco Laboratories, UK), incubated in anaerobiosis at $37{ }^{\circ} \mathrm{C}$ for $48 \mathrm{~h}$, and then the colony-forming units were determined. An enteroinvasive E. coli strain serotype 0124:NM and the noninvasive E. coli HB101 were respectively used as positive and negative controls. All assays were performed in duplicate. Invasion was expressed as the percentage of bacteria recovered from the initial inoculum after antibiotic treatment and lyses of epithelial cells, according to Tang et al. (1993).

\subsection{Cytotoxicity assay}

Bacterial cytotoxicity was assayed on KB tissue culture monolayer (Gaetti-Jardim et al., 2008). Cells were grown in a 96-well microtitration plate (Corning, USA) with L15 minimal medium (Cultilab), added to $2 \%$ fetal bovine serum, and incubated in air $-5 \% \mathrm{CO}_{2}$ at $37^{\circ} \mathrm{C}$ for $48 \mathrm{~h}$. A. actinomycetemcomitans strains were grown in brain heart infusion (BHI) broth and then centrifuged $(13,000 \times g, 5 \mathrm{~min})$. Supernatants were filtered through $0.45-\mu \mathrm{m}$ membrane filters (Millipore, Sao Paulo, $\mathrm{SP}, \mathrm{Brazil})$, and $50 \mu \mathrm{L}$ was added, in duplicate, to the KB cells. After $4 \mathrm{~h}$ of incubation (air-5\% $\mathrm{CO}_{2}$ at $37{ }^{\circ} \mathrm{C}$ ), the results were compared with control cells (without bacterial supernatant). Cytotoxicity was considered when the presence of affected cells was detected. A highly cytotoxic A. actinomycetemcomitans JP2 strain was used as control.

\subsection{Detection of the neuraminidase}

Neuraminidase production was determined by using fresh normal human erythrocytes drawn from healthy volunteers as described by Nakano et al. (2006). The erythrocytes were collected in Alsever's solution (10\%), washed 3 times in $0.01 \mathrm{~mol} / \mathrm{L}$ of $\mathrm{PBS}\left(\mathrm{Na}_{2} \mathrm{HPO}_{4}\right.$, $\mathrm{KH}_{2} \mathrm{PO}_{4}, \mathrm{NaCl}, \mathrm{pH} 7.4$ ), and kept at $4{ }^{\circ} \mathrm{C}$ during 1 week. $A$. actinomycetemcomitans grown in $\mathrm{BHI}$ broth was resuspended to 1.5 $\times 10^{8}$ bacteria/mL. Bacterial suspension was washed 3 times by centrifugation $(12,000 \times \mathrm{g}, 10 \mathrm{~min})$. Then, $1 \mathrm{~mL}$ of bacteria was added to $10 \mu \mathrm{L}$ of washed erythrocytes, achieving a final concentration of $1 \%$, and carefully homogenized and incubated in anaerobiosis at $37^{\circ} \mathrm{C}$ for $4 \mathrm{~h}$. Serial dilutions of peanut lectin $(2.5 \mu \mathrm{g} / \mu \mathrm{L}$ ) (Arachis hypogaea, PNA, Sigma, Sao Paulo, SP, Brazil) in PBS were performed, and $20 \mu \mathrm{L}$ of each dilution was added to a mixture of bacteria-erythrocytes and then homogenized and incubated at room temperature for $1 \mathrm{~h}$, followed by an additional incubation at $4{ }^{\circ} \mathrm{C}$ overnight. The presence of neuraminidase was noticed when an agglutination (bacteria-erythrocyteslectin) was observed. A mixture of bacteria-erythrocytes without lectin was used as negative control (precipitation). The agglutination titer was defined as the reciprocal of the end point dilution.

Inhibition of the neuraminidase production was verified in neuraminidase-positive strains. Briefly, bacteria were treated with 1 
$\mathrm{mL}$ of $1 \mathrm{mmol} / \mathrm{L}$ galactose and then incubated at room temperature for $30 \mathrm{~min}$. Then, $2 \mu \mathrm{L}$ of diluted lectin was mixed with $18 \mu \mathrm{L}$ of bacteria treated with $1 \mathrm{mmol} / \mathrm{L}$ galactose and then added to $20 \mu \mathrm{L}$ of $1 \%$ erythrocytes. Plates were lightly homogenized and incubated at $37{ }^{\circ} \mathrm{C}$ for $1 \mathrm{~h}$, and enzyme inhibition was noticed by precipitation of erythrocytes. A mixture of bacteria-erythrocytes-lectin was used as negative control.

\subsection{Biofilm formation assay}

Biofilm formation was quantified by means of a crystal violet binding assay, as previously described by Kaplan et al. (2003). From A. actinomycetemcomitans grown in BHI broth, $100 \mu \mathrm{L}$ was inoculated into wells of 24-well plates with and without circular glass cover slips (13 mm diameter) containing $1000 \mu \mathrm{L}$ of DMEM medium (4-5 g glucose without antibiotic) (Cultilab) with a 1:10 dilution of bacterial inoculum. After $48 \mathrm{~h}$ of incubation at $37{ }^{\circ} \mathrm{C}$, in a $5 \% \mathrm{CO}_{2}$ atmosphere, medium containing unattached cells was removed. Biofilms were rinsed 3 times with $1 \times$ PBS to remove loosely attached cells, fixed with $75 \%$ ethanol ( $1 \mathrm{~mL}$ per well) for $10 \mathrm{~min}$, and stained with $0.5 \%$ crystal violet for $5 \mathrm{~min}$. The dye bound to the biofilm was extracted with $1 \mathrm{~mL}$ of $95 \%$ ethanol for $2 \mathrm{~min}$, and the absorbance of the crystal violet solution was measured by using a BioRad Benchmark microtiter plate-reader (Sao Paulo, SP, Brazil) set at $A_{595 \mathrm{~nm}}$. All tests were performed in triplicate.

\subsection{Detection of capsule and fimbriae}

Capsules were detected by Hiss staining with modifications (Nakano and Avila-Campos, 2004). A drop of bacterial suspension, from a culture in peptone-yeast extract with $1 \%$ glucose $(1 \%, \mathrm{w} / \mathrm{v})$, was deposited on a microscope slide, covered with crystal violet, and heated until the emission of vapors. Each slide was washed with copper sulfate (20\%, w/v) and allowed to air dry. Capsules were identified under light microscopy as clear areas around the bacteria. The presence of fimbriae was investigated by negative staining with phosphotungstic acid (2\%) and uranyl acetate (2\%), and examined with a Zeiss EM 109 transmission electron microscope (Carl Zeiss, Germany) operated at $80 \mathrm{kV}$ (Nakano et al., 2008).

\subsection{Bacterial DNA}

DNA from A. actinomycetemcomitans was extracted according to Avila-Campos et al. (1999). Briefly, bacterial cells grown in BHI broth were harvested and lysed with $20 \%$ sucrose, $1.4 \mathrm{~mol} / \mathrm{L} \mathrm{Na}_{2} \mathrm{PO}_{4}$, and 10 $\mathrm{mg} / \mathrm{mL}$ lysozyme, and incubated at $37{ }^{\circ} \mathrm{C}$ for $15 \mathrm{~min}$. The lysate was mixed with $0.5 \mathrm{~mol} / \mathrm{L}$ Tris $\mathrm{HCl}, 0.5 \mathrm{~mol} / \mathrm{L}$ EDTA, $10 \mathrm{mg} / \mathrm{mL}$ proteinase
$\mathrm{K}$, and $25 \%$ SDS. DNA was extracted with phenol, sodium perchlorate, and chloroform, and after centrifugation $(5000 \times \mathrm{g}, 5 \mathrm{~min})$ it was precipitated with cold ethanol. DNA was resuspended in $150 \mu \mathrm{L}$ of sterilized TE (10 mM Tris, 1mM EDTA, pH 8.0).

\subsection{Detection of flp-1, apaH, ltx, and cdt genes}

Polymerase chain reaction (PCR) assays were performed by using specific primer pairs (Table 1). Amplifications were performed in volumes of $25 \mu \mathrm{L}$ containing $10 \times$ PCR buffer, $50 \mathrm{nmol} / \mathrm{L} \mathrm{MgCl}_{2}, 0.2$ $\mathrm{nmol} / \mathrm{L}$ dNTP mixture, $0.5 \mathrm{U}$ Taq platinum DNA polymerase, $0.4 \mu \mathrm{mol} / \mathrm{L}$ of each primer and $1 \mathrm{ng}$ template DNA.

DNA amplifications were performed in a thermal cycler (Amp PCR System 9700; Perkin Elmer, Sao Paulo, SP, Brazil), programmed for $94{ }^{\circ} \mathrm{C}(5 \mathrm{~min})$ followed by 30 cycles of $94{ }^{\circ} \mathrm{C}(1 \mathrm{~min}), 50{ }^{\circ} \mathrm{C}$ to $65{ }^{\circ} \mathrm{C}$ ( $1 \mathrm{~min}), 72^{\circ} \mathrm{C}(1 \mathrm{~min})$, and then $72^{\circ} \mathrm{C}(5 \mathrm{~min})$ to allow DNA extension (Table 1). Ultrapure water instead of DNA was used as negative control. PCR products were analyzed by electrophoresis in $1 \%$ agarose gel, stained with ethidium bromide $(0.5 \mu \mathrm{g} / \mathrm{mL})$, and photographed on a UV light transilluminator (Electrophoresis Documentation and Analysis System 120; Kodak Digital Science, Sao Paulo, SP, Brazil). One-kilobase DNA ladder was used as marker.

\subsection{Statistical analyses}

All statistical analyses were performed with GraphPad InStat statistical analysis software (version 3.05, Graphpad Software, San Diego, CA, USA). Data were calculated from 2 experiments and analyzed by the chi-square and Fisher's exact test. A $P<0.05$ was considered significant.

\section{Results}

\subsection{Recovery and biotyping of A. actinomycetemcomitans}

From 65 periodontal patients and 48 healthy subjects, 70 and 3 strains, respectively, were recovered. From 70 strains, 45 belonged to biotype II, 9 to biotype X, 5 to biotype VI, 5 to biotype VIII, 3 to biotype IX, 1 to biotype I, 1 to biotype III, and 1 to biotype V. Of the 3 strains from healthy subjects, 2 belonged to biotype II and 1 to biotype X.

\subsection{Adhesion assay}

Adherence to KB cells was observed in 64 (91.4\%) of 70 strains from periodontal patients and in 2 of 3 strains from healthy subjects

Table 1

Oligonucleotides, annealing temperature, and amplicon sizes used in gene detection.

\begin{tabular}{|c|c|c|c|c|}
\hline Genes & Oligonucleotides $\left(5^{\prime} \rightarrow 3^{\prime}\right)$ & Annealing temperature $\left({ }^{\circ} \mathrm{C}\right)$ & Amplicon (bp) & Reference \\
\hline \multirow[t]{2}{*}{ flp1 } & AAC AAC AAT AGG AGC ATT AAG ACA & 55 & 300 & Kachlany et al. (2001) \\
\hline & GTA TTT AAT ATT TAA GTT GTT ACT TATT & & & \\
\hline \multirow[t]{2}{*}{ apaH } & ATT TAA TCG GCG ACC TGC AC & 52 & 825 & Dogan et al. (1999) \\
\hline & TGT CTT CCC AAC GTA GCA TG & & & \\
\hline \multirow[t]{2}{*}{$c d t A$} & GGT TTA GTG GCT TGT & 50 & 583 & Fabris et al. (2002) \\
\hline & CAC GTA ATG GTT CTG TT & & & \\
\hline \multirow[t]{2}{*}{$c d t B$} & GGT TTT CTG TAC GAT GT & 50 & 790 & Fabris et al. (2002) \\
\hline & GGA TGT AAT TTG TGA GCG T & & & \\
\hline \multirow[t]{2}{*}{ cdtC } & GAC TTT GAC GAG TCA TGC A & 50 & 512 & Fabris et al. (2002) \\
\hline & CCT GAT TTC TCC CCA & & & \\
\hline \multirow[t]{2}{*}{$c d t A B C$} & GGT TTA GTG GCT TGT & 50 & 2065 & Fabris et al. (2002) \\
\hline & CCT GAT TTC TCC CCA & & & \\
\hline \multirow[t]{2}{*}{$\operatorname{lt} x A$} & TCG CGA ATC AGC TCG CCG & 65 & 285 & Tan et al. (2002) \\
\hline & GCT TTG CAA GCT CCT CAC C & & & \\
\hline \multirow[t]{2}{*}{ Ltx (promotor) } & GCA GGA TCC ATA TTA AAT CTC CTT GT & 55 & $530^{\mathrm{a}}$ & Cortelli et al. (2003) \\
\hline & GCG GTC GAC AAC CTG ATA ACA GTA TT & & $1022^{\mathrm{b}}$ & \\
\hline
\end{tabular}

\footnotetext{
a Highly leukotoxic strain.

b Minimally leukotoxic strain.
} 
Table 2

Adhesion and invasion to KB cells by Aggregatibacter actinomycetemcomitans isolated from periodontal and health sites.

\begin{tabular}{|c|c|c|c|c|c|}
\hline \multirow[t]{2}{*}{ Isolates (no.) } & \multicolumn{2}{|c|}{ Adhesion } & \multicolumn{2}{|c|}{ Invasion } & \multirow{2}{*}{$\begin{array}{l}\mathrm{CFU} / \mathrm{mL} \\
\left(10^{3}\right) \\
\text { average }\end{array}$} \\
\hline & $n$ & $\%$ & $n$ & $\%$ & \\
\hline Periodontal patients (70) & 64 & 91.4 & 32 & 50 & 0.2 to 1.4 \\
\hline Health subjects (3) & 2 & 66.6 & 1 & 50 & 0.1 to 10 \\
\hline
\end{tabular}

(Table 2). These values showed statistically significant differences $(P=0.002)$. Adherent bacteria displayed nonlocalized clusters and were easily differentiated from enteropathogenic E. coli 0127:H6 (E2348/69) that displayed a localized adhesion pattern (Fig. 1).

\subsection{Invasion assay}

Thirty-two of the 64 adherent strains from periodontal patients and 1 of 2 adherent strains from healthy subjects were able to invade $\mathrm{KB}$ cells. None of the nonadherent isolates was able to invade KB cells (Table 2). Most of A. actinomycetemcomitans isolated from periodontal patients were able to invade KB cells, but no statistically significant differences were observed $(P=0.110)$.

\subsection{Neuraminidase}

Sixty (82.2\%) of all 73 strains produced neuraminidase with values from 2 to 8 . Galactose was able to inhibit the sialidase activity in all strains.

\subsection{Biofilm}

Fifty-two of 70 strains from periodontal patients and 2 of 3 strains from healthy subjects produced biofilms with values from 0.5 to $>3$. In addition, 18 (25.7\%) produced biofilms with values from $<0.1$ to 0.4 .

\subsection{Detection of capsule and fimbriae}

Capsule was observed by light microscopy in all strains and by transmission electron microscopy as an electron dense layer. No strain showed any fimbriae-like structures, although vesicles on the bacterial surface were observed.

\subsection{Bacterial cytotoxicity on $K B$ cells}

Of the 70 and 3 A. actinomycetemcomitans isolated from periodontal patients and healthy subjects, 44 and 2 strains, respectively, were cytotoxic, producing elongated to rounded cells.

\subsection{Detection of genes}

The apaH and $f l p-1$ genes were detected in 51 (72.9\%) and 38 (54.3\%) strains from periodontal patients and in 1 and 2 strains from healthy subjects, respectively (Fig. 2). All the 70 A. actinomycetemcomitans from periodontal patients harbored the LTX promoter. The ltxA gene was observed in 64 (91.4\%) strains producing bands of $530 \mathrm{bp}$ and in 6 strains producing bands of 1022 bp. In addition, 50 (71.4\%) strains carried the $c d t A$ gene; 48 (68.6\%) strains, the $c d t B$ gene; 60 (85.7\%) strains, the $c d t C$ gene; and 40 (57.1\%) strains, the $c d t A B C$ gene. The 3 strains isolated from healthy subjects harbored the $l t x A$ gene and 1 of them the $c d t C$ gene (Table 3 ).

\section{Discussion}

Aggregatibacter actinomycetemcomitans has been implicated in periodontitis in young subjects, particularly in aggressive periodontitis (Asikainen et al., 1997). This microorganism produces several virulence factors that are involved in oral cavity colonization, destruction of periodontal tissues, and interference with host's defense mechanism (Wilson and Henderson, 1995). Specific biotypes and serotypes of A. actinomycetemcomitans may assume particular importance for disease development (Dogan et al., 1999). In this study, all the 73 strains were grouped into 8 different biotypes; however, most of them belonged to biotype II. A. actinomycetemcomitans biotyping is useful for epidemiologic studies, and, in general, individuals from the same family harbor the same biotype and serotype, suggesting that an intrafamilial route of infection would be partly responsible for the familial nature of the periodontitis (Genco and Loos, 1991).

Several factors have been related to the virulence of A. actinomycetemcomitans, such as fimbriae, sialidases, amorphous structures, and adhesin production, but the role of these factors in adherence is still unclear. Besides, each member of these organisms synthesizes a significant amount of multiple capsular polysaccharides, which are structurally different, suggesting distinct functional properties (Diaz et al., 2006; Fives-Taylor et al., 1996). Surface vesicles have been observed in oral bacteria, such as Porphyromonas gingivalis, and it has been suggested that there is an association between those structures and biological properties, such as proteolysis, hemagglutination, and

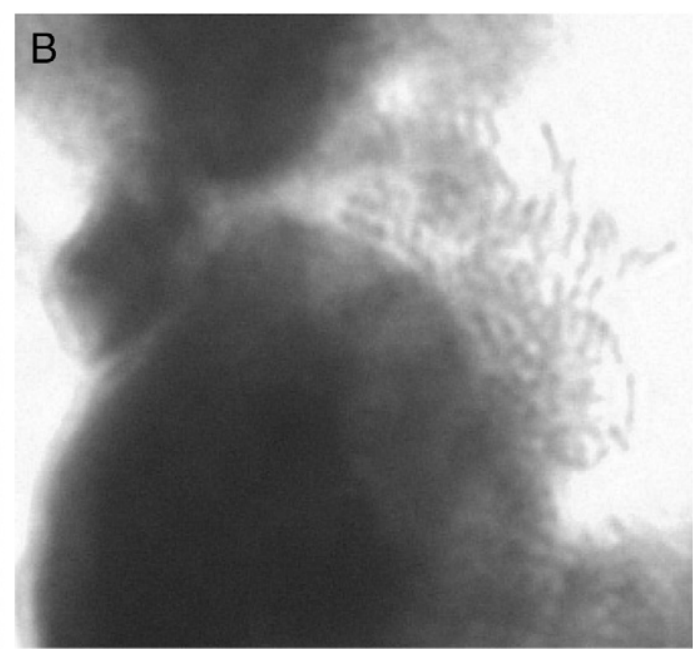

Fig. 1. Adherence to KB cells of A. actinomycetemcomitans (A) and Escherichia coli 0127:H6 (E2348/69) (enteropathogenic) (B). 

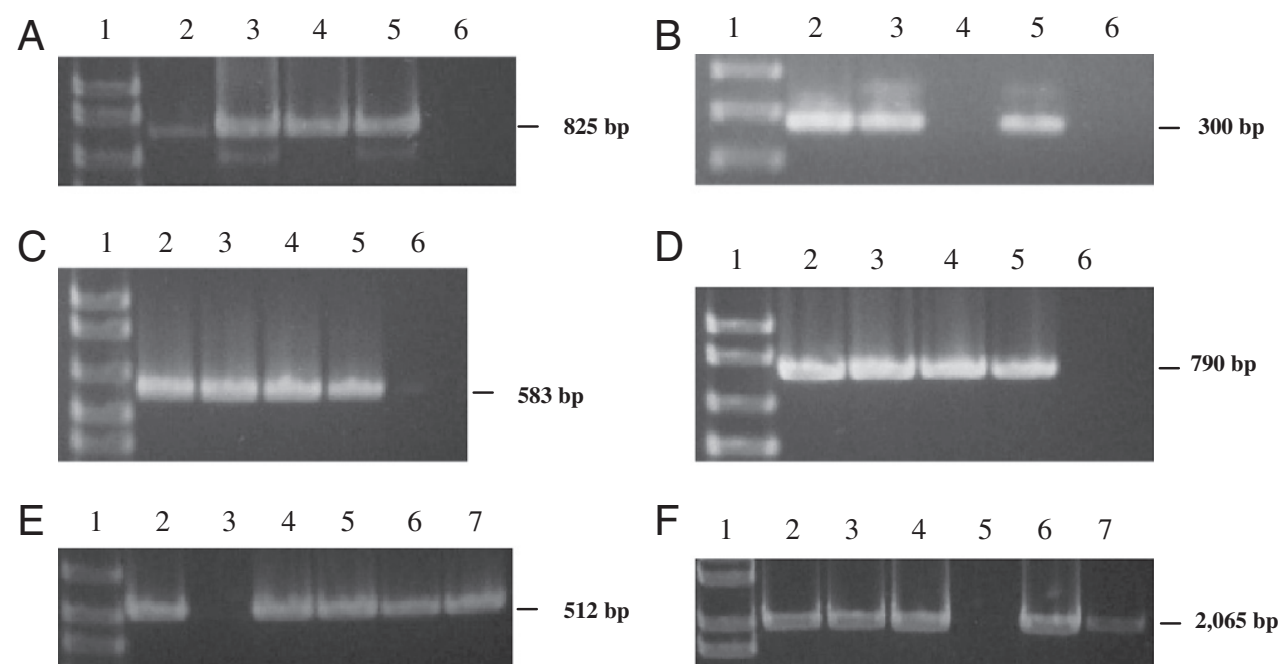

Fig. 2. Detection of the $a p a H(A), f l p 1$ (B), $c d t A(C), c d t B(D), c d t C(E)$, and $c d t A B C$ genes (F) in A. actinomycetemcomitans.

coaggregation. A possible role of vesicles in the virulence includes their ability to disseminate enterotoxin and endotoxin, and also to penetrate epithelial cell barriers.

Encapsulated species are often found in bacterial strains belonging to the resident oral microbiota (Nishihara et al., 1995). Capsule was observed in all the strains; although we did not see a direct correlation with adhesion and invasion, it suggests that, maybe, the capsule is a necessary but not a sufficient factor in this process. The capsular polymer can first protect $A$. actinomycetemcomitans from phagocytosis, and when produced in high amounts, it stabilizes its adhesion to epithelial cells.

Several studies have demonstrated the pathogenicity of encapsulated oral bacteria and their ability to induce abscesses in experimental animals even when inoculated alone. Little is known about the role of the A. actinomycetemcomitans capsular polysaccharide on the host's cells (Henderson et al., 2003; Suzuki et al., 2000).

The KB cell line has been used as a model for gingival epithelial cells on the basis of studies that have shown selective invasion of $A$. actinomycetemcomitans into these cells (Meyer et al., 1991). In this study, fimbriae-like structures were not observed in any of the $66 \mathrm{~A}$. actinomycetemcomitans showing an adherent phenotype, and it is suggested that more than 1 adhesin may be involved and/or outer membrane proteins could be responsible for this process. Pruzzo et al. (1984) affirm that the poor knowledge about this structure is due to the fact that fimbriae require a precise growth condition to be assembled and in low iron concentration and different temperatures affect the expression of this structure.

Fresh clinical strains of A. actinomycetemcomitans are able to adhere tightly to themselves or to substrates, such as glass, plastic, and hydroxyapatite (Fine et al., 1999a; Kachlany et al., 2000). Studies

Table 3

Presence of genes in Aggregatibacter actinomycetemcomitans isolated from periodontal and healthy subjects.

\begin{tabular}{lllllllll}
\hline Isolate no. & \multicolumn{7}{l}{ No. of isolates carrying genes } \\
\cline { 2 - 8 } & $\begin{array}{l}\text { LTX } \\
\text { promoter }\end{array}$ & ltxA & $c d t A$ & $c d t B$ & $c d t C$ & $c d t A B C$ & $a p a H$ & $f l p-1$ \\
\hline Periodontal & $64^{\mathrm{b}}$ & 64 & 50 & 48 & 60 & 40 & 51 & 38 \\
Patients (70) & $6^{\mathrm{c}}$ & 6 & 0 & 0 & 0 & 0 & 0 & 0 \\
Healthy (3) & $3^{\mathrm{c}}$ & 3 & 0 & 0 & 1 & 0 & 1 & 2 \\
Strain JP2 $^{\mathrm{b}}$ & + & + & + & + & + & + & + & + \\
\hline
\end{tabular}

\footnotetext{
a Leutotoxin promoter

b Highly leukotoxic strains (530 bp).

c Minimally leukotoxic strains (1022 bp).
}

have shown that amorphous extracellular material produced by $A$. actinomycetemcomitans collaborates to convert a minimally adherent strain to a highly adherent strain.

It is well established that invasiveness is a prerequisite for the pathology of certain bacterial pathogens (Wilson and Henderson, 1995). A. actinomycetemcomitans displays many factors (fimbriae, hemagglutinin, capsule, lipopolysaccharide, outer membrane vesicles, and enzymatic activities) that can perturb the host's defense mechanisms and initiate tissue destruction; however, no specific invasion mechanisms have been identified. Studies have shown that invasion of human cells by A. actinomycetemcomitans has been limited to some bacterial strains, representing approximately $25 \%$ of invasive A. actinomycetemcomitans (Meyer et al., 1991). On the other hand, it is not known whether the Flp-1 protein is involved in the adhesion to epithelial cells.

The invasion rate of $A$. actinomycetemcomitans was low compared to other periodontal pathogens such as Porphyromonas gingivalis (Nakagawa et al., 2002), and the unusual behavior of leaving and moving from one cell to another within a host cell needs further studies to characterize the mechanisms involved in the invasion process (Meyer et al., 1996). In this study, 50\% of the 66 adherent strains were able to invade epithelial cells and, of these, 38 strains harbored the $\mathrm{flp}-1$ gene. This result suggests that this gene may be in an active or inactive state or that this microorganism needs to express the $f l p-1$ gene by other mechanisms not determined here.

Studies have shown that the flp-1 gene is linked to the $\operatorname{tad} A B C D E F G$ genes, and this gene is found upstream of the tad operon in a low $\mathrm{G}+\mathrm{C}$ region along with 2 other genes ( $r c p A$ and $r c p B$ ) expressed specifically in rough adherent bacteria but not in smooth mutants (Fine et al., 1999b). Our results confirm the findings showing that the level of adhesion is not an indication of the bacterial invasion phenotype. Data support the hypothesis that adhesion and invasion are separate events, and they are mediated by different macromolecules expressed on the outer membrane (Mintz and Fives-Taylor, 1994).

The leukotoxin operon consists, in transcription order, of 4 genes: $I t x C, l t x A, l t x B$, and $l t x D$. The LtxA protein needs to be acylated by LtxC and an acyl carrier protein to become biologically active (Lally et al., 1999). Analysis has revealed that adherent or rough colonies of $A$. actinomycetemcomitans do not secrete leukotoxin but nonadherents or smooth colonies do (Kachlany et al., 2000).

Haubek et al. (2007) have suggested that highly leukotoxic A. actinomycetemcomitans strains comprise a single clone, and, in our study, only 64 strains were considered highly leukotoxic and 6 minimally leukotoxic, which belonged to 8 different biotypes: I, II, III, $\mathrm{V}, \mathrm{VI}, \mathrm{VIII}, \mathrm{IX}$, and X. In addition, biotype II and X were the most 
prevalent, colonizing $12 \%$ and $8 \%$ of the periodontal patients, respectively. In healthy subjects, biotypes II and X were observed. Few studies have shown the presence of biotypes in A. actinomycetemcomitans, and biotype II appears to be the most prevalent in Brazilian periodontal patients (Avila-Campos et al., 1995; GaettiJardim et al., 2008).

Our results show that all the strains were leukotoxic, but no relationship with any biotype was observed. In addition, it is well known that the presence of highly leukotoxic A. actinomycetemcomitans is associated with ecologic and immunologic conditions of the examined population (Haubek et al., 1997). On the other hand, the presence of minimally and highly leukotoxic strains observed in this study was not associated with the development of periodontitis in the analyzed patients. Also, the presence of minimally leukotoxic strains in healthy subjects suggests its possible transitory stage in oral cavity.

The cytolethal distending toxin (CDT) is a cycle-modulatory protein with immunosuppressive function produced by A. actinomycetemcomitans. This toxin is the product of a 3-gene operon (cdtA, $c d t B, c d t C$ ) which is found in a range of bacteria including $E$. coli, Shigella spp., Campylobacter spp., and Helicobacter spp. (Smith and Bayles, 2006). The mechanism of action of this toxin is believed to be due to the nuclease activity of CdtB (Lara-Tejero and Galán, 2000). The CDT of A. actinomycetemcomitans and other bacteria requires all 3 CDT proteins for cell cycle inhibition; however, Shenker et al. (2001) have reported that purified or recombinant A. actinomycetemcomitans CdtB is enough to block human lymphocyte cells.

In this study, 20 of the evaluated strains lacked at least one of the cdt genes as determined by PCR analysis. Forty of these 70 isolated exhibited amplicons when the whole $c d t A B C$ gene operon was amplified using primers homologous to the $c d t A$ and $c d t C$ genes. CDT activity was observed with cell lysates from 5 strains in which $c d t A, c d t C$, or $c d t A B C$ was not detected by PCR. However, the toxic effect of these strains was lower than that observed with lysate from A. actinomycetemcomitans JP2 strain. The absence of amplicons in strains may be explained by the deletion of the genes or the lack of homology with the primers, but it is also possible to observe the presence of a partial deletion without loss of toxin activity. In addition, it has been reported that $c d t C$ is essential for the cytotoxic effect of $A$. actinomycetemcomitans (Shenker et al., 1999). In this study, only 1 strain obtained from healthy subjects harbored the $\operatorname{cdtC}$ gene, and it is suggested that this microorganism could carry an active or inactive gene and it was temporary in the oral microbiota.

Thus, in the present study, we describe the phenotypic and genotypic features of A. actinomycetemcomitans strains isolated from periodontal disease, as well as the in vitro adhesion and cytotoxicity to epithelial cells, and neuraminidase enzyme production. Moreover, 2 of 3 strains from healthy individuals showed potential virulence factors which could cause periodontitis, and, certainly, more studies are necessary to understand the real role of this microorganism in periodontal disease.

\section{Acknowledgment}

The authors thank Marcia H. Fukugaiti and Claudia Trigo Pedroso de Moraes for their technical support.

\section{References}

Asikainen S, Chen C, Saarela M, Saxen U, Slots J. Clonal specificity of Actinobacillus actinomycetemcomitans in destructive periodontal disease. Clin Infect Dis 1997;25: 227-9.

Avila-Campos MJ, Carvalho MAR, Zelante F. Distribution of biotypes and antimicrobial susceptibility of Actinobacillus actinomycetemcomitans. Oral Microbiol Immunol 1995;10:382-4.

Avila-Campos MJ, Sacchi CT, Whitney AM, Steigerwalt AG, Mayer LW. Arbitrary primedpolymerase chain reaction for identification and epidemiologic subtyping of oral isolates of Fusobacterium nucleatum. J Periodontol 1999;70:1202-8.
Brogan JM, Lally ET, Poulsen K, Kilian M, Demuth DR. Regulation of Actinobacillus actinomycetemcomitans expression: analysis of the promoter regions of leukotoxic and minimally leukotoxic strains. Infect Immun 1994;62:501-8.

Cortelli SC, Jorge AO, Cortelli JR, Jordan SF, Haraszthy VI. Detection of highly and minimally leukotoxic Actinobacillus actinomycetemcomitans strains in patients with periodontal disease. Pesq Odontol Bras 2003;17:183-8.

Cravioto A, Gross RJ, Scotland SM, Rowe B. An adhesive factor in strains of Escherichia coli belonging to the traditional infantile enterophatogenic serotype. Curr Microbiol 1979;3:95-9.

Diaz R, Al Ghofaily L, Patel J, Balashova NV, Freitas AC, Labib I, Kachlany SC. Characterization of leukotoxin from a clinical strain of Actinobacillus actinomycetemcomitans. Microb Pathogen 2006;40:48-55.

Dogan N, Saarela M, Jousimies-Somer H, Alaluusua S, Asikainen S. Actinobacillus actinomycetemcomitans serotype e-biotypes, genetic diversity and distribution in relation to periodontal status. Oral Microbiol Immunol 1999;14:98-103.

Fabris AS, DiRienzo JM, Wikstrom M, Mayer MP. Detection of cytolethal distending toxin activity and cdt genes in Actinobacillus actinomycetemcomitans isolates from geographically diverse population. Oral Microbiol Immunol 2002;17:231-8.

Fine DH, Furgang D, Kaplan J, Charlesworth J, Figurski DH. Tenacious adhesion of Actinobacillus actinomycetemcomitans strain CI1000 to salivary coated hydroxyapatite. Arch Oral Biol 1999a:44:1063-76.

Fine DH, Furgang D, Kaplan J, Schreiner HC, Goncharoff P, Charlesworth J, Ghazwan G, Fitzgerald-Bocarsly P, Figurski DH. Phenotypic variation in Actinobacillus actinomycetemcomitans during laboratory growth implications for virulence. Microbiology 1999b; $145: 1335-7$.

Fives-Taylor P, Meyer D, Mintz K. Virulence factors of the peridontopathogen Actinobacillus actinomycetemcomitans. J Periodontol 1996;67:291-7.

Gaetti-Jardim E, Wahasugui TC, Tomazinho PH, Marques MM, Nakano V, Avila-Campos MJ. Distribution of biotypes and leukotoxic activity of Aggregatibacter actinomycetemcomitans isolated from Brazilian patients with chronic periodontitis. Braz J Microbiol 2008;39:658-63.

Genco RJ, Loos BG. The use of genomic DNA fingerprinting in studies of the epidemiology of bacteria in periodontitis. J Clin Microbiol 1991;18:396-425.

Haubek D, DiRienzo JM, Tinoco EM, Westergaard J, López NJ, Chung CP, et al. Racial tropism of a highly toxic clone of Actinobacillus actinomycetemcomitans associated with juvenile periodontitis. J Clin Microbiol 1997;35:3037-42.

Haubek D, Poulsen K, Kilian M. Microevolution and patterns of dissemination of the JP2 clone of Aggregatibacter (Actinobacillus) actinomycetemcomitans. Infect Immun 2007:75:3080-8.

Henderson B, Nair SP, Ward JM, Wilson M. Molecular pathogenicity of the oral opportunistic pathogen Actinobacillus actinomycetemcomitans. Annu Rev Microbiol 2003;57:29-55.

Kachlany SC, Fine DH, Figurski DH. Secretion of RTX leukotoxin by Actinobacillus actinomycetemcomitans. Infect Immun 2000;68:6094-100.

Kachlany SC, Planet PJ, DeSalle R, Fie DH, Figurski DH, Kaplan JB. flp-1, the first representative of a new pilin gene subfamily, is required for non-specific adherence of Aggregatibacter actinomycetemcomitans. Mol Microbiol 2001;40:542-54.

Kaplan JB, Meyenhorfer MF, Fine DH. Biofilm growth and detachment of Actinobacillus actinomycetemcomitans. J Bacteriol 2003;185:1399-404.

Lally ET, Hill RB, Kirba IR, Korosoff J. The interaction between RTX toxins and target cells. Trends Microbiol 1999;7:356-61.

Lara-Tejero M, Galán JE. A bacterial toxin that controls cell cycle progression as a deoxyribonuclease I-like protein. Science 2000;290:354-7.

Meyer DH, Sreenivasan PK, Fives-Taylor PM. Evidence for invasion of a human oral cell line by Actinobacillus actinomycetemcomitans. Infect Immun 1991;59:2719-26.

Meyer DH, Lippman JE, Fives-Taylor PM. Invasion of epithelial cells by Actinobacillus actinomycetemcomitans: a dynamic multistep process. Infect Immun 1996;64: 2988-97.

Mintz KP, Fives-Taylor PM. Adhesion of Actinobacillus actinomycetemcomitans to human oral cell line. Infect Immun 1994;62:3672-8.

Moncla BJ, Braham P, Hillier SL. Sialidase (neuraminidase) activity among Gramnegative anaerobic and capnophilic bacteria. J Clin Microbiol 1990;28:422-5.

Nakagawa I, Amano A, Kobiniwa M, Nakamura T, Kawabata S, Hamada S. Functional differences among FimA variants of Porphyromonas gingivalis and their effects on adhesion to and invasion of human epithelial cells. Infect Immun 2002;70:277-85.

Nakano V, Avila-Campos MJ. Virulence markers and antimicrobial susceptibility of bacteria of Bacteroides fragilis group isolated from stool of children with diarrhea in São Paulo, Brazil. Mem Inst Oswaldo Cruz 2004;99:307-12.

Nakano V, Piazza RMF, Avila-Campos MJ. A rapid assay of the sialidase activity species of the Bacteroides fragilis group by using peanut lectin hemaggluination. Anaerobe 2006;12:238-341.

Nakano K, Inaba H, Nomura R, Nemoto H, Tamura K, Miyamoto E, Yoshioka H, Taniguchi K, Amano A, Ooshima T. Detection and serotype distribution of Aggregatibacter actinomycetemcomitans in cardiovascular specimens from Japanese patients. Oral Microbiol Immunol 2007;22:136-9.

Nakano V, Piazza RMF, Cianciarullo AM, Bueris V, Santos MF, Menezes MA, MendesLedesma MRB, Szulczewski V, Elias WP, Pumbwe L, Wexler H, Avila-Campos MJ. Adherence and invasion of Bacteroidales isolates from the human intestinal tract. Clin Microbiol Infect 2008;14:955-63.

Nishihara T, Ueda N, Amano K, Ishihara Y, Hayakawa H, Kuroyanagi T, Ohsaki Y, Nagata K, Noguchi T. Actinobacillus actinomycetemcomitans Y4 capsular-polysaccharidelike polysaccharide promotes osteoclast-like cell formation by interleukin-1 alpha production in mouse marrow cultures. Infect Immun 1995;63:1893-8.

Pruzzo C, Dainelli B, Ricchetti M. Piliated Bacteroides fragilis strains adhere to epithelial cells and are more sensitive to phagocytosis by human neutrophils than nonpiliated strains. Infect Immun 1984;43:189-94. 
Saito T, Ishihara K, Ryu M, Okuda K, Sakurai K. Fimbriae-associated genes are biofilmforming factors in Aggregatibacter actinomycetemcomitans strains. Bull Tokyo Dent Coll 2010;51:145-50.

Shenker BJ, McKay T, Datar S, Miller M, Chowhan R, Demuth D. Actinobacillus actinomycetemcomitans immunosuppressive protein is a member of the family of cytolethal distending toxins capable of causing a G2 arrest in human T cells. J Immunol 1999;162:4773-80.

Shenker BJ, Hoffmaster RH, Zekavat A, Lally NET, Demuth D, Yamaguchi N. Induction of apoptosis in human $\mathrm{T}$ cells by Actinobacillus actinomycetemcomitans cytolethal distending toxin is a consequence of $G_{2}$ arrest of the cell cycle. J Immunol 2001;167: 435-41.

Slots J. Selective medium for Actinobacillus actinomycetemcomitans. J Clin Microbiol 1982;15:606-9.

Slots J, Ting M. Actinobacillus actinomycetemcomitans and Porphyromonas gingivalis in human disease: occurrence and treatment. Periodontol 2000 1999;20:82-121.

Slots J, Reynolds HS, Genco RJ. Actinobacillus actinomycetemcomitans in human periodontal disease: a cross-sectional microbiological investigation. Infect Immun 1980;29:1013-20.
Smith JL, Bayles DO. The contribution of cytolethal distending toxin to bacterial pathogenesis. Crit Rev Microbiol 2006;32:227-48.

Suzuki N, Nakano Y, Yoshida Y, Nakao H, Yamashita Y, Koga T. Genetic analysis of the gene cluster for the synthesis of serotype a-specific polysaccharide antigen in Actinobacillus actinomycetemcomitans. Biochem Biophys Acta 2000;1517:135-8.

Tan KS, Song KP, Ong G. Cytolethal distending toxin of Actinobacillus actinomycetemcomitans. Occurrence and association with periodontal disease. J Periodontal Res 2002;37:268-72.

Tang P, Foubister V, Pucciarelli MG, Finlay BB. Methods to study bacterial invasion. J Microbiol Methods 1993;18:227-40.

Whitehouse CA, Balbo PB, Pesci EC, Cottle DL, Mirabito PM, Pickett CL Campylobacter jejuni cytolethal distending toxin causes a G2-phase cell cycle block. Infect Immun 1998;66:1934-40.

Wilson M, Henderson B. Virulence factors of Actinobacillus actinomycetemcomitans relevant to the pathogenesis of inflammatory periodontal diseases. FEMS Microbiol Rev 1995; $17: 365-79$

Xie H, Cai S, Lamont RJ. Environmental regulation of fimbrial gene expression in Porphyromonas gingivalis. Infect Immun 1997;65:2265-71. 